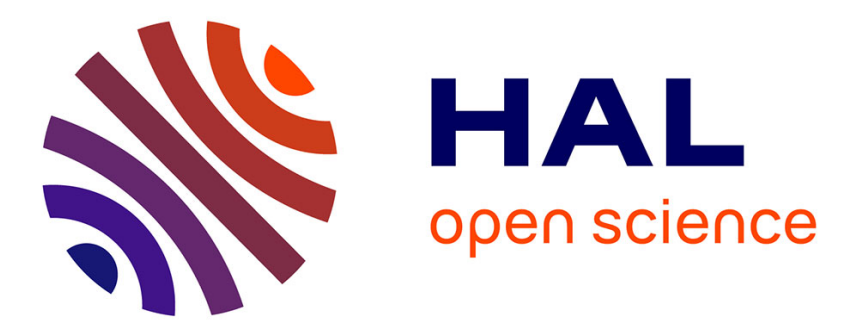

\title{
Central Bank Transparency and the consensus forecast: What does The Economist poll of forecasters tell us?
}

Emna Trabelsi

\section{To cite this version:}

Emna Trabelsi. Central Bank Transparency and the consensus forecast: What does The Economist poll of forecasters tell us?. Research in International Business and Finance, 2016, 38, pp.338-359. 10.1016/j.ribaf.2016.04.004 . hal-01121434v3

\section{HAL Id: hal-01121434 \\ https://hal.science/hal-01121434v3}

Submitted on 8 Jun 2016

HAL is a multi-disciplinary open access archive for the deposit and dissemination of scientific research documents, whether they are published or not. The documents may come from teaching and research institutions in France or abroad, or from public or private research centers.
L'archive ouverte pluridisciplinaire HAL, est destinée au dépôt et à la diffusion de documents scientifiques de niveau recherche, publiés ou non, émanant des établissements d'enseignement et de recherche français ou étrangers, des laboratoires publics ou privés. 


\title{
Central Bank Transparency and the consensus forecast: What does The Economist poll of forecasters tell us?
}

\author{
Emna Trabelsi*
}

\begin{abstract}
We are interested, in this paper, in studying the effects that central banks exert on private sector forecasts by means of their transparency and communication measures. We analyze the impact of central bank transparency on the accuracy of the consensus forecasts (usually calculated as the mean or the median of the forecasts from a panel of individual forecasters) for a series of macroeconomic variables: inflation, Real output growth and the current account as a share of GDP for 7 advanced economies. Interestingly, while it is found of significance of central bank transparency and communication measures on forecasts themselves, there appear some limits of the same measures when we study their impact on forecast errors. Our findings, indeed, suggest that deviations of the economic forecast data from the realized ones (RGDP and the current account as a share of GDP) are a bit affected by the central bank transparency measures considered in the paper. Inflation forecast errors, especially, are not affected at all by those measures. A possible explanation (among others) could be attributed to the inefficiency of the mean forecasts. Inefficiency of the consensus forecasts is not a new issue from a theoretical point of view, but its empirical relevance is for the first time (to our knowledge) questioned on data extracted from the Economist poll of forecasters. More particularly, our paper extracts practical implications over the effectiveness of transparent announcements in forecast formation process. We rely on two noisy information models, though having different mechanisms (Kim et al, 2001; Morris and Shin, 2002) both of which are consistent with overweighting issue to explain the inefficiency of the consensus forecast.
\end{abstract}

Keywords: Transparency, Communication, Consensus forecasts, Economist poll of forecasters, Inefficiency

JEL codes: B22, C23, E58

\footnotetext{
E-mail: emna.trabelsi2007@yahoo.fr.

Address: University of Tunis. Institut Supérieur de Gestion de Tunis. 41 Avenue de la Liberté, cité Bouchoucha, le Bardo, 2000, Tunisia. Mobile: 0021621310931.
} 


\section{Introduction}

Nowadays, transparency practices are seen as a successful premise in achieving the objectives, especially those applied in monetary policy framework. The prompted rise of central bank transparency is derived from the view that transparency is a prerequisite for accountability in an era of independence (Dincer and Eichengreen, 2014).

We address an empirical focus on the effects that central banks exert on private sector forecasts by means of their transparency and communication measures.

The central bank's public disclosure about monetary policy and regular assessment of economic developments attracts market participants. This is helpful for the markets to understand how systematic, the response of monetary policy to economic development and shocks, and to anticipate the overall stance of monetary policy over the medium term. Markets can thus develop more efficient and accurate forecasts, thereby allowing for a quick implementation of monetary policy in financial variables. In recent years, central banks around the world have increased the volume of information they offer to the public. For example, many central banks have become more explicit about the long-run objectives of monetary policy such as long-run inflation objectives. Central bank transparency is warranted because such a practice generates important benefits including more effective monetary policy (Sellon, 2008). Markets don't only react to central bank's announcements because they are valuable, but also because other markets participants will react to the same disclosure. However, public disclosure may serve as a "double-edge" sword and could lead to inefficient outcomes (Morris and Shin, 2002).

In this paper, we use rarely exploited data ${ }^{1}$ contained in the Economist poll of forecasters and investigate whether, or to what extent central bank communication and increased transparency have affected both the level and the accuracy of private agents' forecasts of inflation and other economic variables.. There exists an extensive literature on forecasts, forecast accuracy, and their response to central bank's policies. Bauer et al. (2008) looked at the effects of changes in Fed's communication policy on macroeconomic forecasts taken from Blue Ship Economic Indicators report and found that the publication of FOMC statements in addition to the Fed's rate decisions didn't reduce the forecast errors. In the same context, Hubert (2013) examined the usefulness of information contained in FOMC macroeconomic forecasts (central bank's forecasts) using data from the Survey of Professional Forecasters (SPF). Another strand of the literature is closer to our framework. It assessed the effect of increased central bank communication and transparency on private expectations ${ }^{2}$. Capistran and Ramos-Francia (2010) and Gürkaynak et al. (2010), among others, studied the effect of inflation targeting on private forecasts. Most of the previous papers concentrate either on a specific component of central bank's communication and transparency policy (for example the adoption of inflation targeting regime taken as a variable of interest) or they consider the dispersion of inflation expectations as the response variable. We contribute to the existing literature by, first, evaluating the impact of central bank's practices on forecasts both in terms of level and accuracy. The second aim of the paper is to discuss the (in)efficiency issue of the consensus forecast as a proxy of private-sector's expectations. The associated test is carried out by calculating the forecast revisions and their correlation with the forecast errors.

We are aware of two papers of Siklos $(2003,2010)$ exploring data from the Economist poll of forecasters. We deviate, however, from his approach in, at least, five main aspects:

\footnotetext{
${ }^{1}$ Most of the related papers use data from Consensus Economics, Blue ship Indicators, Survey of Professional Forecasters, Wall Street Journal..., etc

${ }^{2}$ We take a look further at some papers in the empirical analysis (see section.3).
} 
1. Siklos $(2003,2010)$ focused mainly on inflation ${ }^{3}$ in level and inflation forecast disagreement, while our study addresses the consensus forecast and covers other key economic indicators. More importantly, the current account as a share of GDP is rarely discussed in forecasting literature.

2. We include a set of controls susceptible to affect the forecasts. We fill this gap by including the appropriate determinants to predict future inflation, RGDP and the current account as a share of GDP besides the variables of interest ${ }^{4}$;

3 . We extend the analysis to include more transparency and communication variables. Precisely, we use the multidimensional index of transparency ${ }^{5}$ constructed by Dincer and Eichengreen $(2010,2014)$.

4. It is worth exploring whether increased transparency and communication levels influence private sector process formation. It is, also, of utter importance to test how the forecast accuracy is affected as we need to make sure that most transparent central banks ensure lower levels of forecast errors.

5.We contribute to the literature on the forecast efficiency by seeing how aggregating all the monthly incoming information by the forecasters is a challenging task.

We believe our study could interest both policy makers and researchers as it offers further insights on how effective the central bank transparency and communication are in improving the accuracy of the private sector expectations. The beliefs that the private sector forms about the central bank's announcements in forecasting are important because they determine ultimately the inflation and the output, outcomes, even though those forecasts don't match the central bank's policy rule.

The remainder of the paper is as follows; section 2 presents the theoretical basis of our framework, section 3 describes the empirical analysis, including description of data used and presents the main results of estimations. Section 4 offers further interpretations of those results. Section 5 concludes.

\section{Theoretical deliberations}

Before analyzing data, we present an illustrative (and simple) framework that motivates our empirical analysis. Prior research on accuracy and consensus forecasts' efficiency showed that forecasters use both public (common) and private information in forming predictions. Therefore, if these forecasts are efficient, they will incorporate all available information. In a model where analysts possess this information in the form of noisy signals about the analysts' beliefs, these beliefs diverge. The problem arises from two possible facts. (i) either the forecasters take into account irrelevant information (ii) or they underweight the private information. The main result referred the phenomenon to as "inefficiency of the mean forecast". Morris and Shin (2002) considered the same data-generating process described above, but added a beauty contest element ${ }^{6}$. They stated that more accurate public information can increase the average error of the private sector because forecasters attempt to second guess each other by placing a weight on the common signal in excess of the optimal Bayesian weight when forming expectations. Hence, the public signal reflected in the consensus forecast plays a dual role: (i) it conveys information about the fundamental state (information role) (ii) it is a coordination device of the views of other forecasters (commonality role). Crowe (2010b)

\footnotetext{
${ }^{3}$ Inflation and GDP are the most variables subject to analysis in previous studies.

${ }^{4}$ We mean central bank transparency and communication variables.

${ }^{5}$ For instance, Siklos (2010) found that transparency increases the inflation forecast disagreement in a cross-country study of 9 economies

${ }^{6}$ They formalized the Keynesian beauty contest model.
} 
provided an excellent reassessment of both arguments and showed that the negative (eventual) consequences of a more transparent public information should not be on the grounds of the presence of a coordination motive (i.e. the beauty contest element) in the guessing-game of Morris and Shin $(2002)^{78}$. Drawing upon both papers, we give a brief description:

There's a continuum of agents who receive two types of signals on an unknown fundamental $\theta$, one is a purely private signal that is independent among agents $\left(\mathrm{pr}_{i}\right)$, and the other is a purely public $(p u)$ signal that is perfectly correlated among agents?

$$
\left\{\begin{aligned}
\theta & =p u+\eta & \eta & \sim N\left(0, \sigma_{\eta}^{2}\right) \\
p r_{i} & =\theta+\varepsilon_{i} & & \varepsilon_{i} \sim N\left(0, \sigma_{\varepsilon}^{2}\right)
\end{aligned}\right.
$$

Using Bayesian update rule, the first-order expectation is the weighted sum of both signals shown in Eq.1

$$
E_{i}(\theta)=\frac{\sigma_{\varepsilon}^{2}}{\sigma_{\varepsilon}^{2}+\sigma_{\eta}^{2}} p u+\frac{\sigma_{\eta}^{2}}{\sigma_{\varepsilon}^{2}+\sigma_{\eta}^{2}} p r_{i}
$$
be

It follows from Eq. 2, the average expectation of the fundamental (the mean forecast) would

$$
\bar{E}(\theta)=\int E_{i}(\theta) d i=\frac{\sigma_{\varepsilon}^{2}}{\sigma_{\varepsilon}^{2}+\sigma_{\eta}^{2}} p u+\frac{\sigma_{\eta}^{2}}{\sigma_{\varepsilon}^{2}+\sigma_{\eta}^{2}} \theta
$$

Agents form forecasts so that they minimize the mean squared forecast error $E(\bar{E}(\theta)-\theta)^{2}$. By differentiating with respect to $\sigma_{\eta}^{2}$, we obtain

$$
\frac{\partial E(\bar{E}(\theta)-\theta)^{2}}{\partial \sigma_{\eta}^{2}} \leq 0 \Leftrightarrow \sigma_{\varepsilon}^{2} \leq \sigma_{\eta}^{2}
$$

According to Eq.4, greater transparency $\left(\partial \sigma_{\eta}^{2} \leq 0\right)$ can increase the consensus forecast error if the public signal is initially noisier than agents' own signals.

If the consensus forecast overweights public information, it is inefficient. In fact, the mean forecast is negatively correlated with its forecast errors, while the individual forecasts are not.

$$
E(\bar{E}(\theta)(\bar{E}(\theta)-\theta))=-\frac{\sigma_{\eta}^{4} \sigma_{\varepsilon}^{2}}{\left(\sigma_{\varepsilon}^{2}+\sigma_{\eta}^{2}\right)^{2}} \leq 0
$$

\footnotetext{
${ }^{7}$ The model assumes that agents form expectations so that they minimize a loss function, which is a weighted sum of the mean squared forecast error and the mean squared deviation of individual forecasts from the consensus. In other terms, not only agents are concerned about the fundamentals, but also other agents' behavior. The argument has been subject to further discussion and developments in many papers both from theoretical and experimental side.

${ }^{8}$ Although we present both theoretcial arguments, we rely more on the work of Morris and Shin (2002) as the landmark that best fits the context of central bank policies and monetary policy (see Morris and Shin, 2008).

${ }^{9}$ Crowe (2010b) considered a purely public signal and an imperfectly correlated private signal.
} 
To put the above theoretical arguments into the test, we first assess the response of the consensus forecasts, in level, to central bank's communication and transparency policies. Then, we turn to evaluate the relationship between the same variables of interest and the quality of forecasts in terms of accuracy and examine the forecasting properties (efficiency).

\section{$3 \quad$ Econometric modelling}

\subsection{Model, data and preliminary sketch}

One of the impediments to transparency-economic forecasts, relationship was the dearth of data on central bank transparency index. At least, empirical literature dedicated to studying the effects of central bank transparency and communication practices focused on the impact of inflation targeting regime adoption on the forecasts. Crowe (2010a) analyzed the behavior of private sector forecasts of inflation in eleven inflation targeting countries. The findings were consistent with the fact that this regime improves forecasting accuracy of private sector. Crowe and Meade (2008) found that enhanced transparency practices are associated with the private sector, making greater use of information of central banks. While most of the empirical studies focus on economic forecasts, Middeldorp (2011) looked at the response of the interest rate using a multi country panel data. Hubert (2014) conducted an interesting study on the influence of ECB communication variables (by distinguishing quantitative versus qualitative) on inflation forecasts, including another set of controls that could affect the forecasts.

Another more recent strand of literature focused on the determinants of disagreement using individual expert forecasts from the frequent source Consensus Economics (see Ehrmann et al., 2012; Dovern et al., 2012).

In our paper, we explore data from the Economist poll of forecasters covering the period November 2001 to December 2010. They are gathered and downloaded from http://www.oecd.org/eco/surveys/18635847.htm. The Economist surveys a group of 15 financial forecasters - including The Economist Intelligence Unit and 14 international banks from the financial centers- on a monthly basis and calculates the average of their annual predictions for the key macroeconomic variables: economic growth, inflation, and current account balances for 15 countries and the Euro-Area. The private sector forecasts are, thus, reflected in the consensus (average) forecasts included in the Economist. The polls performed in January and February of every year; contain the forecasts for data of the previous and the current calendar year. From March to December, the forecast reports to the current and the following calendar year. In testing the impact of central bank transparency on macroeconomic forecasts, we introduce both inflation and non-inflation targeting countries since data from the Economist poll of forecasters are available for a short country sample. ${ }^{10} \mathrm{We}$ add the content and the quality of inflation report as another more specific measure of transparency. It forms the main information tool used by central banks to communicate with the public. The frequency of this report differs among central banks (Table B.2). We created a dummy variable set 1 if there is release of such a report at month $\mathrm{t}$ and 0 otherwise. A more general index of transparency is given by Dincer and Eichengreen $(2010,2014)^{11}$. They assign $0,1 / 2$ or 1 points to each of the fifteen questions and they sum up them. According to the overall measure, the Sveriges Riksbank (Central bank of Sweden) is the most transparent central bank in 2010 with a score of 14.5. The Federal Reserve joined also the top ten of the most transparent central

\footnotetext{
${ }^{10}$ We dropped countries for which the transparency score is not available. Note that after 2006, Denmark is not listed in the set of economies considered by The Economist. Hence, the second sample will comprise only the six remaining countries. Furthermore, the length of both samples is affected by the absence of data prior to 2001 .

${ }^{11}$ Dincer and Eichengreen (2010) updated the transparency index until 2006 and then they re-updated it until 2010 in their second paper (Dincer and Eichengreen, 2014). The overall score takes values between 0 and 15 .
} 
banks with a score of 11 the same year. Overall, it makes a sense to observe a higher degree of transparency for OECD countries since they are better able to process information (Figure A.1).

Empirically, we assess the effect of transparency and communication variables on the forecasts through the following Eq:

$$
\boldsymbol{E}_{s}\left(\boldsymbol{x}_{i t}\right)=\alpha+\beta_{x} \boldsymbol{x}_{i t \mid s-1}+\beta_{\Phi} \Phi_{i t}+\beta_{\Gamma} \Gamma_{i t-1}+\varepsilon_{i t}
$$

Where $\boldsymbol{x}_{\boldsymbol{i} t \mid s-1}$ is the actual (annual) lagged variable to be forecast. $\Phi$ contains the three communication and transparency variables of interest: Central bank transparency index of Dincer and Eichengreen (2010, 2014), the inflation report (labelled as comm) and inflation targeting dummy. $\Gamma$ encompasses the macroeconomic controls: output gap as a percentage of potential GDP, the oil price (Europe Brent spot price) and the unemployment rate is used to represent cyclical positions (Minegishi and Cournède, 2009). To adhere to the information timing structure, we regress private forecasts on controls at date $\mathrm{t}-1 / \mathrm{s}-1$ since the pollsters collect and publish their forecasts at the beginning of each month ${ }^{12}$. We suppose that forecasts are formed based on the information set $\Gamma$ from the previous month/year. Eq. 5 is estimated first for forecasts formed at month $t$ of the current year $\mathrm{s}$ made during the current year $\mathrm{s}$. The same Eq is then replicated for forecasts formed at month $t$ of the next year $s+1$ made in the current year s. In other terms:

$$
\boldsymbol{E}_{s}\left(\boldsymbol{x}_{i t}\right)=\left\{\begin{array}{l}
\boldsymbol{E}_{s}\left(\boldsymbol{x}_{i t}\right)_{\mid s}: \\
\text { is the consensus forecast of the macroecono mic variable } \boldsymbol{x} \text { of the current years } \\
\text { made during the current year s. } \\
\boldsymbol{E}_{s}\left(\boldsymbol{x}_{i t}\right)_{\mid s+1}: \\
\text { is the consensus forecast of the macroecono mic variable } \boldsymbol{x} \text { of the next years }+1 \\
\text { made during the current year s. }
\end{array}\right.
$$

The Philips curve links inflation to the output gap positively. The oil price shall have a positive incidence on inflation and current account as a share of GDP. $i$ refers to the country and $t$ refers to the monthly period frequency. Details about variables and source are available in Table B.1. Lastly, we run Feasible Generalized Least Square (FGLS) regression. The method requires two conditions: (i) The panel is strongly balanced; (ii) The time dimension exceeds the cross-sectional dimension $(T>N)$.

Graphs offer an intuitive way to illustrate the role that transparency may play in forecasting. Figure A.2 presents expected US growth for 2005, the expected US current account/GDP ratio for 2005 and US consumer price inflation for 2005 as predicted by the Economist poll of forecasters from March 2004 to February 2006. Note that all the data points are predictions for the same period, for example for the calendar year of 2005. However, they differ since the forecasters continuously update their information set. As seen in the second graph, for example, forecasters became increasingly optimistic about US growth for 2005 during the year of 2004. But, over the course of 2005, their forecasts declined slightly from the peak.

The comparison between forecasts (of the current year and the next year, respectively) and their realized values is made available through their plot in Figures A.3-A.8. They show the pollsters' monthly inflation, growth and the current account balance predictions for all countries

\footnotetext{
12 We follow Ehrmann et al. (2012) and Hubert (2014).
} 
considered in the panel under the period 2001-2010. The gap between the projections and realized values shrinks at the end of each year in most cases.

\subsection{Effect of Central bank transparency and communication on forecasts}

We estimate different variants of the model (1) for different forecasts. Line (1) contains the estimates testing for the importance of releasing the inflation/monetary policy report. Lines (2) and (3) combine two central bank transparency and communication measures with the lowest correlation coefficients in a joint model for both samples.

\subsubsection{Results for the sample (2001-2006)}

Multivariate estimations reported in the first part of Tables B.3.1-B.3.3 confirm that comm has a negative effect on both current and next-year inflation forecasts.

Overall transparency index of Dincer and Eichengreen (2010) is, however, not significant. Introducing inflation targeting (IT) in the model is to alter the behavior of macroeconomic forecasts. This binary variable has a positive and significant impact only on next-year inflation forecasts.

Three interpretations of these results emerge: (i) The disclosure of monetary policy/inflation reports leads forecasters to decrease their inflation expectations by 10 to $13 \%$. (ii) The introduction of inflation targeting regime plays a distinctive role in terms of impact on forecasts (iii) No clear evidence that enhanced transparency (introduced itself in the regression) necessarily (and directly) affects inflation forecasts. From an initial point of view, this result is due, in a part, to the slow change of the transparency index which is annual and is sometimes stable through years in some countries considered in the sample.

A slight change to the original specification is made through including an interaction term (inflation $\times$ transparency). The rationale behind this new regression is that if greater transparency successfully anchors inflation expectations, they should exhibit a lower response to changes in actual inflation. This point identifies a negative and significant impact of the interaction term (transparency index $\times$ actual inflation) on inflation forecasts. The result shows that where central banks are more transparent, expected inflation is less sensitive to changes in inflation outcome.

Our variables of interest (Overall transparency index, communication and inflation targeting dummy) have all a significant impact on RGDP and the current account as a share of GDP and go into the same direction for the latter. That is, they have a positive effect on the above mentioned forecasts, except the release of inflation report (comm) which exerts a negative impact on RGDP.

Moreover, lagged actual outcome, the oil price, the output gap and the unemployment rate appear to add a highly (depending on the control variables) significant value to inflation private expectation formation. The same result holds for the other dependent variables considered in our study (RGDP forecast, current account as a \% of GDP).

\subsubsection{Results for the sample (2001-2010)}

Following the first sample, the first issue examined is whether the index of transparency $(T)$ and the release of inflation reports (labelled as "comm") influence private sector forecasts of inflation, growth and current account balance and whether noticeable differences exist between countries that formally target inflation and other major central banks that haven't adopted inflation targeting regime yet. Regressions were re-estimated in a panel setting to assess whether private sector inflation forecasts are affected by the publication of an inflation report 
(a one-dimensional indicator of transparency), by the general indicator of transparency updated by Dincer and Eichengreen (2014) (which is multidimensional), and the requirement to meet numerical inflation targets (an indicator of greater accountability). As explained earlier, Eq. 5 allows for controlling the relationship between forecasts and their corresponding actual lagged data, prevailing at the time of projection. The associated coefficient is highly significant and large for all (current and next-year) macroeconomic variables as seen in the second part of Tables B.3.1-B.3.3. The results reveal that most of transparency and communication measures (The variables of interest) have a significant impact on current-year and next-year forecasts of inflation, growth and on the current account as a share of GDP, respectively. Hence, the panel estimates suggest that these types of policy initiatives play a significant role in influencing inflationary expectations, growth and balance projections. There's a stretch also to think that run up on oil prices was driving inflation expectations with a significant increase of about 0.6 (current-year) to $0.9 \%$ (next- year) and of about $1 \%$ (current-year) and $0.9 \%$ (next- year) for the current account as a percentage of GDP. The same variable has a significant - but non monotonic - impact on Real GDP growth. To sum up, the results of the second sample follow (almost) the same pattern as in the first sample. We observe a particular improvement related to the transparency score, which becomes significant and has a positive effect on next-year inflation forecasts. The output gap is apparently an important determinant of inflation forecast with statistically significant positive effects. Note that an important feature of our results shows that the signaling content of a multidimensional index (the transparency score of Dincer and Eichengreen $(2010,2014)$ ) and a one-multidimensional communication variable (for example the release of inflation/monetary policy report) is different and suggests that both types of transparency and communication tools are not substitutes.

\subsection{Effect of Central bank transparency and communication on forecast accuracy}

Significant coefficients on transparency and communication measures mean that those measures play a role in forecasting, but don't necessarily imply that transparency really enhances forecasting. Whether central bank transparency is beneficial or harmful, we need a further examination of the former on the reduction of forecast dispersion. To achieve this aim, we need a measure of the forecast accuracy by looking at magnitudes of deviations from benchmarks. For that purpose, one could follow Mankiw et al. (2003), Siklos (2010), Ehrmann et al. (2012) and Dovern et al. (2012) by analyzing the impact of transparency and communication indicators on forecasts dispersion through the width of the Interquartile (IQR) range $^{13}$ (difference between the third and quartile of observations). Doing this seems to be impractical because of the format of private forecasts used throughout the paper. In fact, that measure requires taking into account the disagreement - cross sectional dispersion of individual forecasts - about the key economic indicators. Data on individual forecasts, however, are not available in the case of the Economist poll of forecasters. We choose then to work with the Mean Absolute Error (MAE). The latter is used to measure how close mean (consensus) forecasts are to the eventual outcomes. The Eq to be estimated is now given by the following expression:

$$
\left|\boldsymbol{E}_{s}\left(\boldsymbol{x}_{i t}\right)-\boldsymbol{x}\right|=\alpha+\beta\left|\boldsymbol{E}_{s}\left(\boldsymbol{x}_{i t-1}\right)-\boldsymbol{x}\right|+\beta_{\Phi} \Phi_{i t}+\beta_{\tilde{\Gamma}} \tilde{\Gamma}_{i t-1}+\varepsilon_{i t}
$$

\footnotetext{
${ }^{13}$ On could use also the standard deviation but IQR are still more robust to outliers than standard deviations.
} 
Where $\left|\boldsymbol{E}_{s}\left(\boldsymbol{x}_{i t}\right)-\boldsymbol{x}\right|$ is the difference between the consensus forecast and its realization in absolute value. $\Phi$ contains the three variables of interest: Central bank transparency index of Dincer and Eichengreen (2010, 2014), inflation report (labelled as comm) and inflation targeting dummy. $\tilde{\Gamma}$ encompasses the macroeconomic controls: the absolute change in oil price (Europe Brent spot price). Eq.6 is estimated first for forecasts formed at month $t$ of the current year s made during the current year $\mathrm{s}$. The same equation is then replicated for forecasts formed at month $t$ of the next year $s+1$ made in the current year $s$. In other terms:

$$
\left|E_{s}\left(x_{i t}\right)-x\right|=\left\{\begin{array}{l}
\left|E_{s}\left(x_{i t}\right)_{\mid s}-x_{\mid s}\right|: \\
\text { is the absolute forecast error of the macroeconomic variable } x \text { of the current year s } \\
\text { made during the current year s. } \\
\left|E_{s}\left(x_{i t}\right)_{\mid s+1}-x_{\mid s+1}\right|: \\
\text { is the absolute forecast error of the macroeconomic variable } x \text { of the next year s }+1 \\
\text { made during the current year s. }
\end{array}\right.
$$

\subsubsection{Results for the sample 2001-2006}

Tables B.4.1-B.4.3 provide the parameter estimates of Eq.6. Transparency $(T)$ and communication (comm) measures seem to influence significantly RGDP, and a bit the Current Account as a percentage of GDP, while the same measures don't affect inflation. The results of the other control variables show that the deviation of the macroeconomic forecasts from their realized values is indeed persistent. The own lag has statistically significant and sizable coefficient. We also compared the behavior of average absolute forecast errors in targeting and non-targeting countries. This is illustrated by the introduction of the dummy variable IT in the regression. The literature doesn't provide strong evidence that targeting regimes experience lower average absolute forecast errors (or Mean Absolute Error) relative to the non-targeting countries. For example, Johnson (2002) showed a decline in inflation forecasts, but not in errors or variance. Cechetti and Hakkio (2010) didn't find also any convincing evidence of reduction in the dispersion of inflation forecasts in a sample of 15 countries. Both papers focused only on the impact of inflation targeting regime adoption on inflation forecast errors and/or their variability.

\subsubsection{Results for the sample 2001-2010}

The second part of Tables B.4.1-B.4.3 shows the results of the same measures' impact on the accuracy of forecasts. Eq. 6 allows for some persistence in absolute forecast errors by adding lagged values. The corresponding coefficient is highly significant in all cases. The results for the other control variables indicate that they have their expected signs. Oil price changes seem to affect the forecast accuracy of all our key economic indicators. It is clear that there are some cases where more transparency and communication lead to a reduction of the Mean Forecast Error (MAE) by exhibiting a negative coefficient. The reduction remains, however, insignificant in most cases. More precisely, those practices appear to influence a bit significantly RGDP and the current account as a percentage of GDP, respectively. While the same practices don't affect at all inflation mean forecast errors. 
We have to be mindful that we don't extract a strong and effective amelioration of forecast accuracy in our econometric estimates. On the one hand, the powerful effect of transparency is somewhat absorbed because the score's level is already high for central banks considered in our sample while transparency shall be particularly powerful at low levels (Ehrmann et al., 2012). On the other hand, realizations must be conceived (normally) in a way against which ex ante expectations are compared to. We only observe forecast error ex post that might be less accurate under greater transparency.

\section{$4 \quad$ Interpretation and further discussion}

The puzzling relationship between central bank transparency and inflation forecast accuracy can be derived from further suspicious reasons and facts:

1. An important caveat in our study is that we tried to detect the effects and the influence of the overall transparency index on forecasts and forecast accuracy, respectively. The overall index is the preferred measure in the empirical analysis because it encapsulates all the dimensions of transparency. The literature provides furthermore, evidence that transparency about economic objective (A particular dimension of transparency according to the typology of Geraats, 2002) has particularly important macroeconomic effects. That special sub-component of transparency has been subject to a test and the results of the corresponding estimations are reported in Table B. $5^{14}$. We also take into account the endogenous aspect of that variable by regressing it on the rule of law ${ }^{15}$. Eq. 6 is estimated by instrumental variables (IV) and two-stages-least square (2SLS) to identify the causal effect of economic transparency. We find that this latter exerts a negative and significant influence on current-year inflation forecasts. The same subindex appears also to improve - though insignificantly- the forecast accuracy of inflation $^{16}$.

2. While some evidence provided so far points to a powerful tool of central bank transparency and communication in affecting forecasts and their accuracy; the question turns to investigate whether there are limits to this role. In fact, van der Cruijsen et al. (2010) found a non- linear effect of transparency on inflation through a quadratic form. They introduce interaction terms: lagged inflation times the transparency index and lagged inflation time the squared transparency index. The relationship is consistent with the existence of an optimal threshold above which more transparency turns to be harmful. A particular level of 7.5 is found for OECD countries and that level is already exceeded by the central banks considered in our paper.

3. Monetary policy affects inflation with rather long lags (1.5 to 2 years); to reflect possible effects of enhanced central bank transparency (see Ehrmann et al., 2012).

4. A possible explanation can be attributed to the inefficiency of the consensus forecasts which can be a result of overweighting old information.

A further examination of the fourth point forms the second purpose of this paper. We proceed to an analysis of the forecast revisions through their correlation with forecast errors. Such a statistical exercise can reveal important observations on how efficiently forecasters react to new information. Analyzing the dynamics of forecast revisions, has received particular

\footnotetext{
14 These estimates shall be considered as a robustness check.

${ }^{15}$ Other governance indicators are also tested as instruments. They don'tm howeverm improve the regression fit.

16 The coefficient sign of both overall and economic transparency becomes negative.
} 
attention by numerous studies ${ }^{17}$, focusing first on developed countries (see Isiklar et al, 2006). More recent contributions add specific attention to emerging countries. Dovern et al. (2015), among others, assessed the performance of forecasts in both advanced and emerging economies and arrived at the conclusion that developed countries incorporate information faster than the emerging countries. Yet, the difference is still small. They also observed that GDP consensus forecasts are updated every 6 months. This result concurs with that of Loungani (2001) and Loungani et al. (2013) who found that it takes the forecasters 4-6 months to update their forecasts to fully reflect new information. Unlike previous papers, Chen et al. (2016, forthcoming) chose a sample covering Asian economies and showed that forecasters underreact to new information more in advanced economies than in emerging economies. Overall, they noted a forecast improvement from long to short horizons. In the case of interest rate, Middeldorp (2011, p.28) claimed that "it seems plausible that any information asymmetries between policy makers and professional forecasters are likely to be greatest in the short term..."

In our case, we follow Crowe (2010b) methodology and define the forecast error as the difference between the consensus forecast and the realization. The forecast revision (or forecast update) is given by the difference between the current forecast and the previous one. The consensus forecasts present the advantage of an explicit revision of 24 forecasts (with horizons varying from 1 to 24 ) for every target year that can be observed. To understand the structure of the publication of the monthly consensus forecast, more clearly, we consider the following comprehensive forecast made at the beginning of March of the year $\mathrm{s}$ for the target year $\mathrm{s}$ (current year). The realized (actual) value is known only 10 months later at the end of the year $(\mathrm{h}=10)$. In the same month, forecasters made their predictions of the target year $\mathrm{s}+1$ (next year). The realized value is released 22 months-ahead $(\mathrm{h}=22)$ (see Figure A.9 for illustration). The results of the correlations between the forecast revisions and the forecast errors are displayed in Table B.6 in ascending horizon $(\mathrm{h}=1,2, \ldots ., 24)$. For RGDP, the hypothesis of a negative correlation cannot be rejected for horizons between 10 and 16 months-ahead. The sign is still negative, but turns to be insignificant for the remaining horizons, suggesting an overall systematic underreaction to new information. In the case of inflation, the conclusions vary. For short horizons, the sign ranges between positive and negative, while still insignificant for the latter. The cut-off point up to which the rejection of the hypothesis of a negative and significant correlation between forecast errors and forecast revisions remains is at horizon $=11$. That behavior is restored starting from $\mathrm{h}=17$. Finally, the forecasters don't incorporate new information properly into their prediction of the current account as a share of GDP especially at short horizons. The associated coefficient is highly significant. Turning, now, to the results of the inefficiency test across horizons; most of the correlation coefficients have negative signs but significant only for Real output growth. Altogether, the negative estimates mean underweighting new information (similarly overweighting older information); while the insignificance shows that the observed inefficiency cannot be fully attributed to information aggregation (Crowe, 2010).

Note that our sample spans a period that comprises two major events: the subprime mortgage crisis of 2007-07 and the financial crisis of 2008-09, both of which triggered the known global financial crisis. So, examining the forecast pattern (before and during the crisis) becomes a crucial exercise. As we did earlier, we re-estimate the pairwise correlations for the sub-sample Nov 2001-Dec 2006. The signs are negative mostly for inflation and RGDP, but less significant compared to the whole sample (especially for RGDP). Apparently, the forecast inefficiency is more pronounced during years with a pernicious financial crisis because forecastsers fail to adjust their predictions in a consistent manner in response to incoming information. This is

\footnotetext{
${ }^{17}$ Note that those studies differentiate between the dynamics of individual forecast revisions vs consensus foerecast revisions. Therefore, the associated results are dependent on whether individual forecasts or consensus forecasts are considered in the analysis.
} 
almost in accordnance with previous studies that rejected efficiency for a wide range of countries based both on consensus forecasts (Loungani, 2001; Isiklar et al, 2006; Ager et al, 2009) and on individual forecasts (Davies and Lahiri, 1995; Lahiri and Sheng, 2008).

\section{Conclusion}

We have studied the extent to which central bank transparency and communication have contributed to influencing the expectations of economic agents, by testing their effects on the forecasts of key economic indicators and their corresponding absolute forecast errors, respectively using the Economist poll of forecasters. The findings of the paper indicate that there's a significant (overall) influence of transparency on private sector forecast formation. Forecasters in countries with more transparent and open central banks update their expectations in response to news. At the same time, when the question turns to appraise the contribution of transparency and communication measures in terms of enhancement of forecast accuracy, those practices seem not being always good. While there's a bit evidence of significant communication and/or adoption of inflation targeting regime on RGDP and the current account as a share of GDP, the absolute forecast errors of the inflation rate are not affected at all by the variables of interest considered in this study. A deeper interpretation of this fact can be added: More transparent public information can decrease the accuracy of the consensus forecast and better public information could lead to worse collective opinions. There's also appeal of more caution when using the consensus forecasts as proxies for expectations because they don't form the best (and the most efficient) estimate of the true state of the world. The correlation coefficient between the mean forecast and its revision, though negative, is significant only for RGDP, which means that inefficiency cannot be due only to information aggregation. It is worth noting that the second sample includes an important event which is the global financial crisis 2007-2008. The crisis might have the effect of underweighting new information by the forecasters and lead to an increase in the mean absolute forecast errors. However, this could not be totally attributed to such an event because we observe almost the same pattern followed by the first sample ${ }^{18}$, ending before the crisis triggered in the econometric results. The effect of the crisis is, however, pronounced when analyzing statistically the forecast revisions. Overall, we think that there may be a mixture of reasons mentioned in the main text. An incoming research could focus on emerging countries and analyze empirically if their transparency and communication practices affect the forecast accuracy. While the problem of transparency indicator is solved as it is already - and generously- available for a large country sample, a handicap persists with the small size of the cross-country ${ }^{19}$ data set of the Economist poll of forecasters. Thereby, the use of a larger expectation survey data set becomes especially appealing. We can go ahead with a data collection from (www.fx 4 casts.com), recently explored by Miah et al. (2016, forthcoming) ${ }^{20}$ to test the efficiency of inflation expectations. In such a case; we expect there may have differences -though slight- in forecast smoothing (efficiency) between advanced and emerging economies (Loungani et al., 2013; Dovern et al., 2015). Nonetheless, our results also suggest a potentially promising avenue for future research to understand deeply the major drivers of forecast errors and to better assess the forecast revision behavior by using the same database (The Economist poll of forecasters).

\section{Acknowledgements}

\footnotetext{
${ }^{18}$ It gives a supplementary justification of the use of two samples in our empirical analysis.

${ }^{19}$ The existing data are relative to advanced economies.

${ }^{20}$ The authors focused on the question of the efficiency of inflation expectations and arrive at the conclusion of forecasts' unbiaisedness while controlling for other sources of information (monetary supply, oil price) for 18 emerging economies.
} 
We thank the participants of $10^{\text {ème }}$ Colloque International ISG Sousse 2015 for useful feedback on an earlier draft. We are grateful to the editor and anonymous referees for comments that significantly improved the manuscript.

\section{Appendix}

\section{A. Figures}

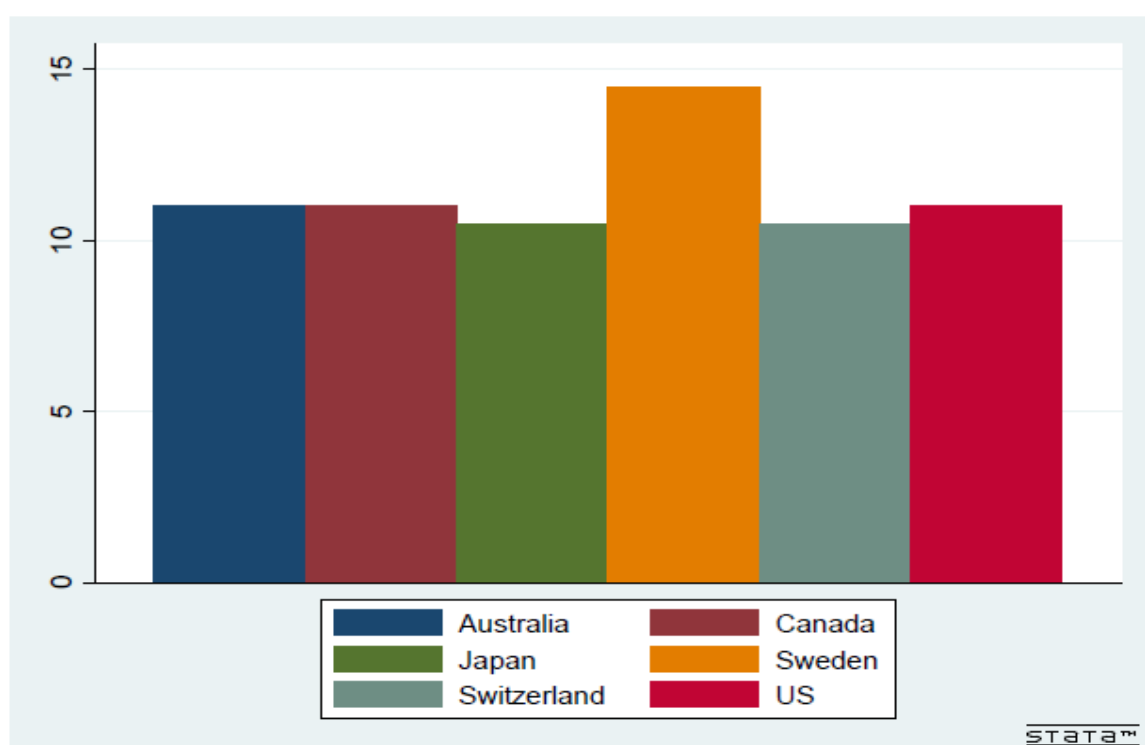

Fig A.1. Transparency index in 2010 for countries considered in our sample

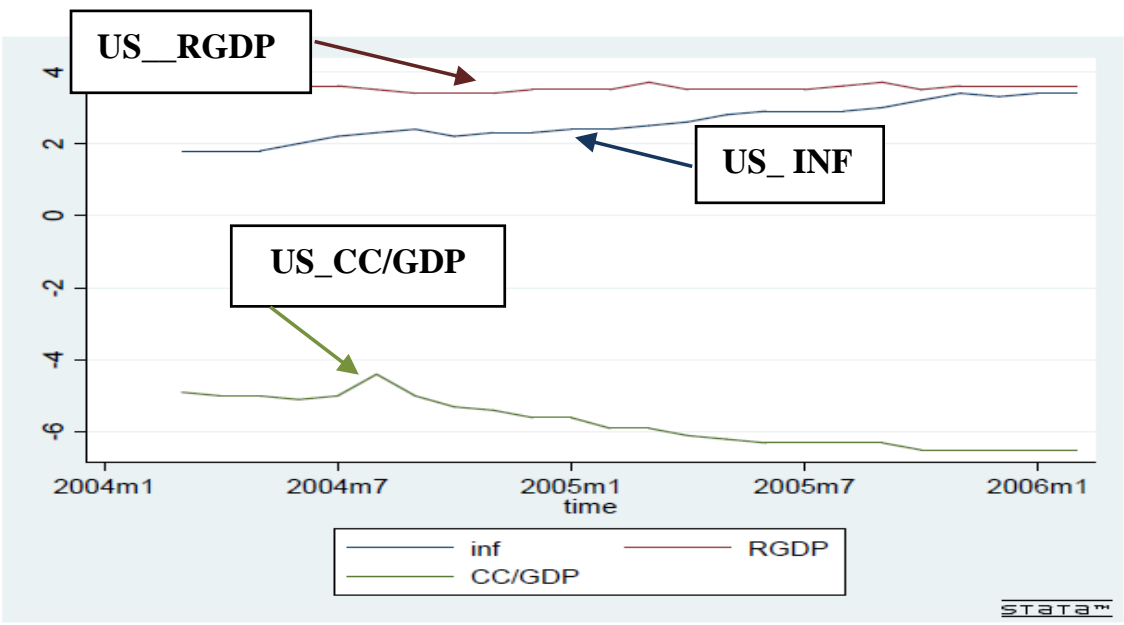

Fig A.2. Example of an expectation mechanism in the United States (US) 03/200402/2006. Inf refers to inflation, RGDP refers to Real Gross Domestic Product, and CC/GDP refers to Current Account as a \% of GDP 


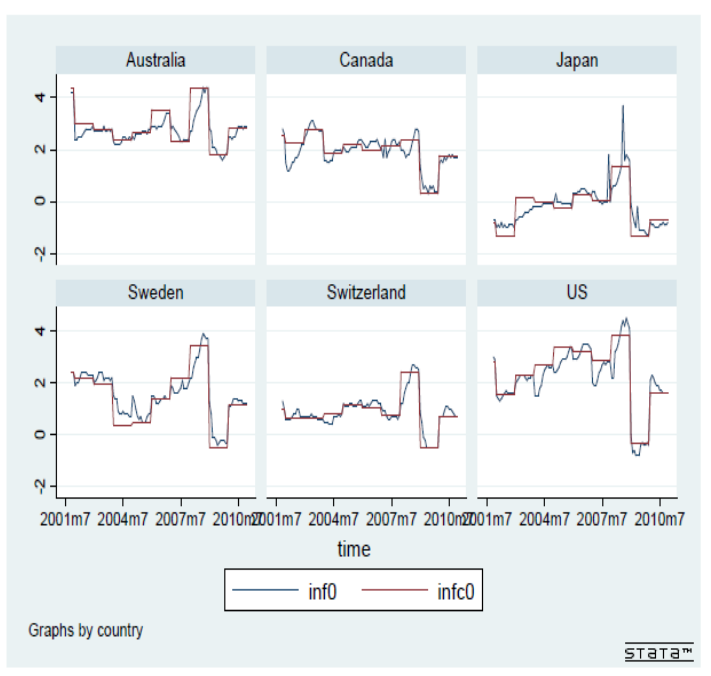

Fig A.3. Realized versus inflation forecast of the current year: November 2001- December 2010 inf0: inflation forecast of the current year. infc0: actual inflation

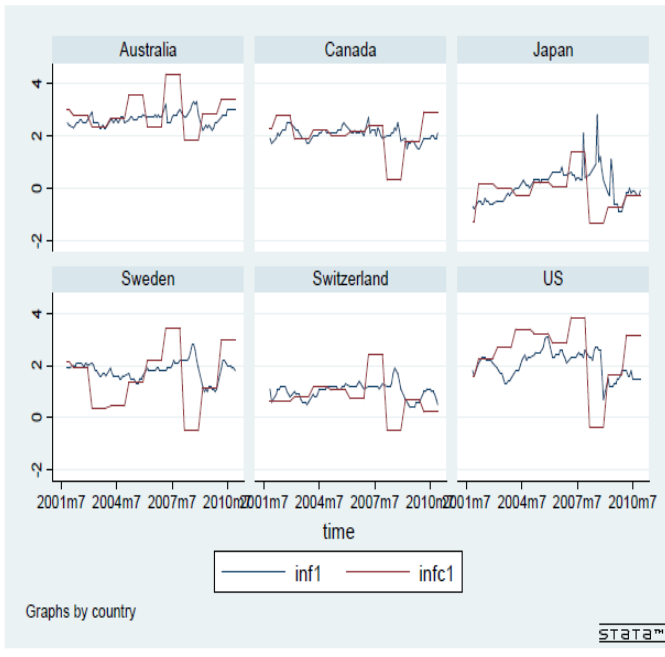

Fig A.4. Realized versus inflation forecast of the next year: November 2001- December 2010 inf1: inflation forecast of the next year. infc1: actual inflation

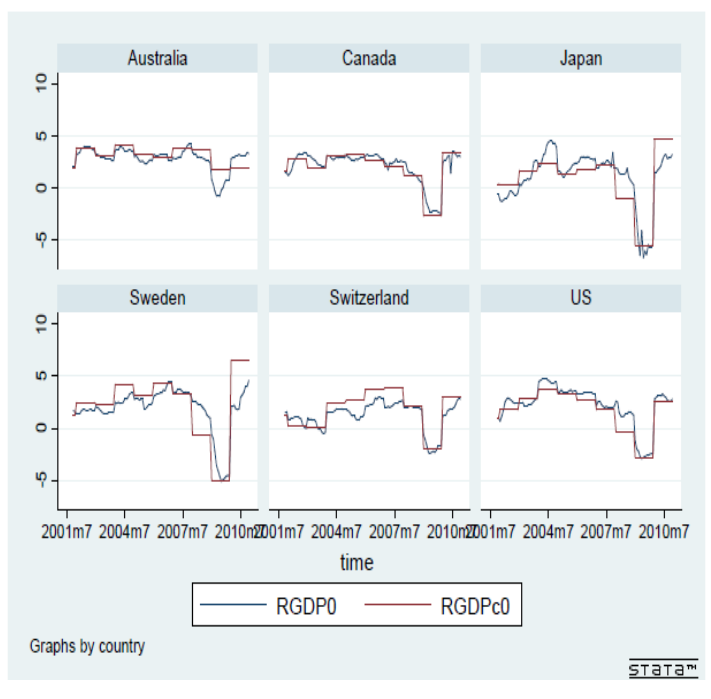

Fig A.5. Realized versus Real Gross domestic product forecast of the current year: November 2001- December 2010

RGDP0: RGDP forecast of the current year. RGDPc0: actual RGDP

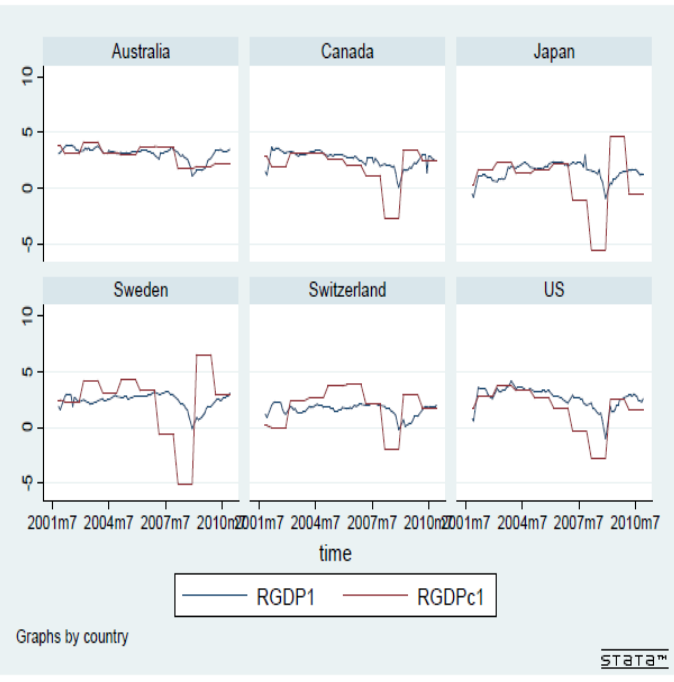

Fig A.6. Realized versus Real Gross domestic product forecast of the next year: November 2001December 2010

RGDP1: RGDP forecast of the next year. RGDPc1: actual RGDP 


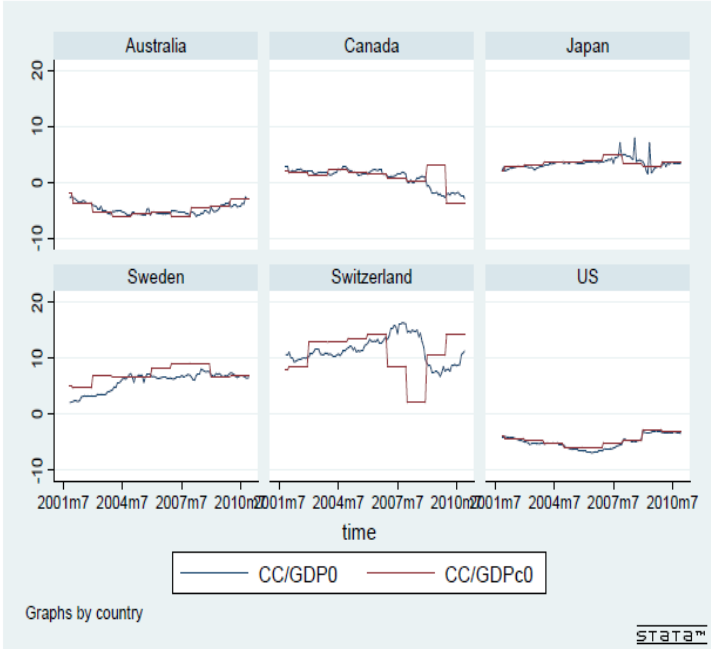

Fig A.7. Realized versus current account as a share of GDP forecast of the current year: November 2001- December 2010

CC/GDP0: current account as a share of GDP forecast of the current year. CC/GDPc0: actual current account as a share of GDP

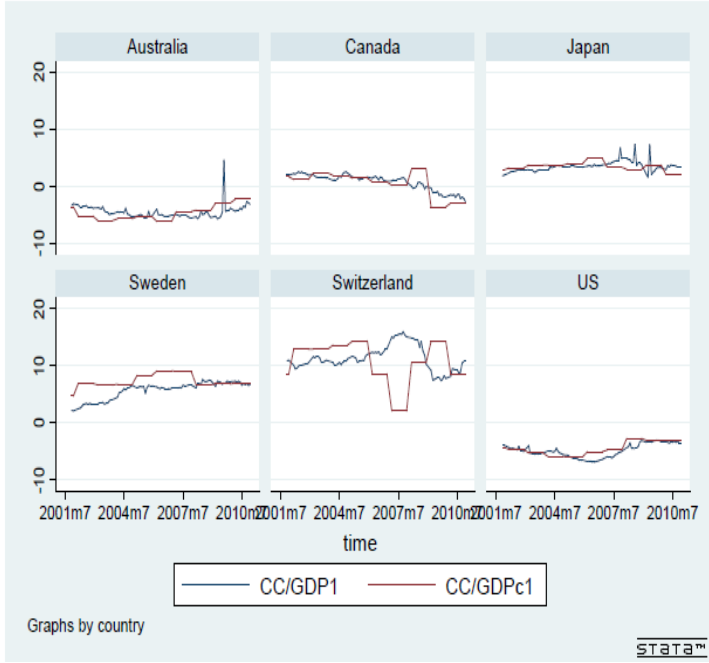

Fig A.8. Realized versus current account as a share of GDP forecast of the next year: November 2001- December 2010

CC/GDP1: current account as a share of GDP forecast of the next year. CC/GDPc1: actual current account as a share of GDP
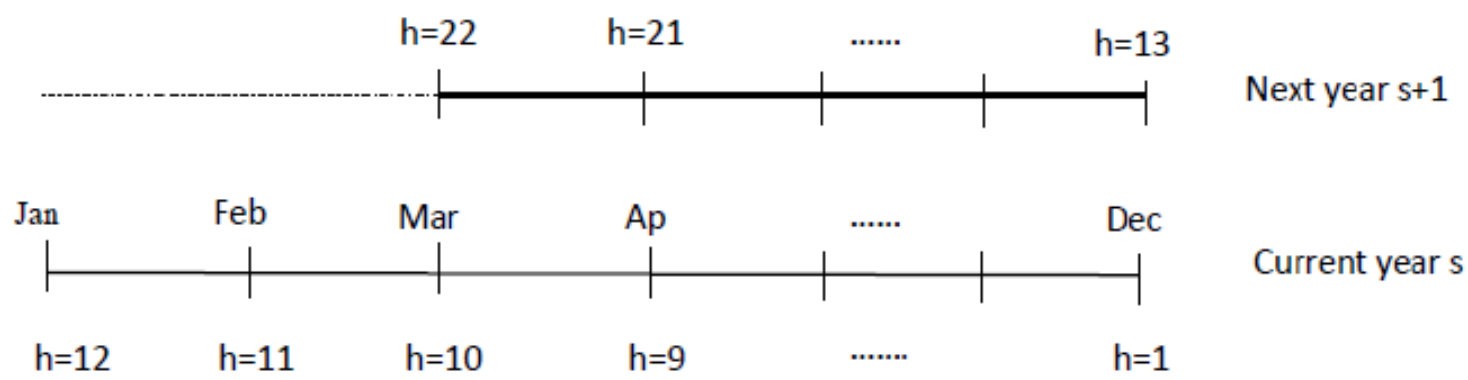

Fig A.9. Structure of monthly consensus forecasts according to different horizons 
Table B.1

\section{B. Tables}

Data and their related sources

\begin{tabular}{|c|c|c|}
\hline Variable & Description & Source \\
\hline \multicolumn{3}{|c|}{ Macroeconomic forecasts } \\
\hline Inflation & $\begin{array}{l}\text { Percentage increase in Consumer } \\
\text { Price Index }\end{array}$ & $\begin{array}{l}\text { Economic and Financial indicators } \\
\text { http://www.economist.com/ or } \\
\text { http://www.oecd.org/eco/surveys/18635847.htm. }\end{array}$ \\
\hline RGDP & Real Gross Domestic Product & $\begin{array}{l}\text { Economic and Financial indicators } \\
\text { http://www.economist.com/ or } \\
\text { http://www.oecd.org/eco/surveys/18635847.htm. }\end{array}$ \\
\hline CC/RGDP & $\begin{array}{l}\text { Current account as a percentage of } \\
\text { GDP }\end{array}$ & $\begin{array}{l}\text { Economic and Financial indicators } \\
\text { http://www.economist.com/ or } \\
\text { http://www.oecd.org/eco/surveys/18635847.htm. }\end{array}$ \\
\hline \multicolumn{3}{|c|}{ Measures of Transparency and communication } \\
\hline$T$ & Transparency score & $\begin{array}{l}\text { Dincer and Eichengreen }(2010,2014) \\
\text { Available also at: http://eml.berkeley.edu/ eichengr/data.html }\end{array}$ \\
\hline$I T$ & $\begin{array}{l}\text { Dummy }=1 \text { starting the period of } \\
\text { inflation targeting adoption and } 0 \\
\text { otherwise }\end{array}$ & Pétursson (2004) \\
\hline comm & $\begin{array}{l}\text { Inflation/monetary policy report as } \\
\text { a dummy }=\text { if there's release of a } \\
\text { report and } 0 \text { otherwise }\end{array}$ & Central Bank websites (see Table B.2 for details) \\
\hline \multicolumn{3}{|c|}{ Other control variables } \\
\hline Outgap & Output gap & $\begin{array}{l}\text { OECD outlook database } 96 \\
\text { http://stats.oecd.org/index.aspx?queryid=51396\# }\end{array}$ \\
\hline Unemp & Unemployment rate & $\begin{array}{l}\text { OECD outlook database } 96 \\
\text { http://stats.oecd.org/index.aspx?queryid=51396\# }\end{array}$ \\
\hline Oil & Europe Brent Spot price & $\begin{array}{l}\text { St Louis Fed } \\
\text { http://research.stlouisfed.org/fred2/series/DCOILWTICO/downloa } \\
\text { ddata }\end{array}$ \\
\hline$|\Delta o i l|$ & $\begin{array}{l}\text { The absolute change on oil prices } \\
\text { in the preceding month }\end{array}$ & $\begin{array}{l}\text { St Louis Fed } \\
\text { http://research.stlouisfed.org/fred2/series/DCOILWTICO/downloa } \\
\text { ddata }\end{array}$ \\
\hline $\mathrm{Inf}_{-1}$ & Actual lagged inflation (annual) & $\begin{array}{l}\text { International Financial Statistics (IFS) } \\
\text { http://elibrary-data.imf.org/DataExplorer.aspx }\end{array}$ \\
\hline$R G D P_{-1}$ & $\begin{array}{l}\text { Actual lagged Real Gross } \\
\text { Domestic Product (annual) }\end{array}$ & $\begin{array}{l}\text { Economic Research Service } \\
\text { http://www.ers.usda.gov/data-products.aspx }\end{array}$ \\
\hline$C C / G D P_{-1}$ & $\begin{array}{l}\text { Actual lagged current account as } \\
\text { a percentage of GDP (annual) }\end{array}$ & $\begin{array}{l}\text { http://www.economywatch.com/economic-statistics/economic- } \\
\text { indicators/Current_Account_Balance_Percentage_GDP/ }\end{array}$ \\
\hline Governance & icators & $\begin{array}{l}\text { Worldwide Governance Indicators } \\
\text { http://info.worldbank.org/governance/wgi/ }\end{array}$ \\
\hline
\end{tabular}

Table B.2

Frequency of inflation/monetary policy report. Source: central bank websites

\begin{tabular}{lll}
\hline Australia & Quarterly & Monetary policy statement \\
\hline Canada & Quarterly & Monetary policy report \\
\hline Sweden & Quarterly & Inflation report \\
\hline Switzerland & Quarterly & Bulletin \\
\hline United States & Half-yearly & Monetary policy report \\
\hline Japan & Monthly & Bulletin \\
\hline Denmark & Quarterly & Monetary policy review \\
\hline
\end{tabular}


Table B.3.1

Transparency and inflation forecasts

\begin{tabular}{|c|c|c|c|c|c|c|c|c|c|c|c|c|c|c|c|c|}
\hline \multirow[b]{3}{*}{$\alpha$} & \multicolumn{4}{|c|}{ Current year } & \multicolumn{4}{|l|}{ Next year } & \multicolumn{4}{|c|}{ Current year } & \multicolumn{4}{|l|}{ Next year } \\
\hline & \multicolumn{4}{|c|}{$\boldsymbol{E}_{s}\left(\inf _{i t}\right)_{\mid s}$} & \multicolumn{4}{|c|}{$\boldsymbol{E}_{s}\left(\inf _{i t}\right)_{\mid s+1}$} & \multicolumn{4}{|c|}{$\boldsymbol{E}_{s}\left(\inf _{i t}\right)_{\mid s}$} & \multicolumn{4}{|c|}{$\boldsymbol{E}_{s}\left(\inf _{i t}\right)_{\mid s+1}$} \\
\hline & $-0.314 * * *$ & $-0.319 * *$ & $-0.303 * * *$ & $-0.304 * * *$ & 0.101 & -0.071 & 0.016 & 0.103 & $0.363 * * *$ & 0.272 & -0.028 & $0.373 * * *$ & $0.787 * * *$ & 0.210 & $0.445^{* * *}$ & $0.786^{* * *}$ \\
\hline & $(-4.06)$ & $(-2.06)$ & $(-3.73$ & $(-3.93)$ & $(1.50$ & $(-1.68)$ & $(0.24)$ & $(1.54)$ & (3.06) & $(1.12)$ & $(-0.22)$ & (3.18) & (9.55) & $(1.23)$ & $(5.22)$ & (9.67) \\
\hline \multirow{2}{*}{ comm $_{i t}$} & $-0.126^{* * *}$ & $-0.125 * * *$ & $-0.143 * *$ & $-0.124 * * *$ & $-0.098 * *$ & $-0.106^{* * *}$ & $-0.133 * * *$ & $-0.096 * *$ & $-0.355 * * *$ & $-0.351 * * *$ & $-0.242 * * *$ & $-0.354 * * *$ & $-0.291 * * *$ & & - & $-0.288 * * *$ \\
\hline & $(-2.63)$ & $(-2.62)$ & $(-2.47)$ & $(-2.58)$ & $(-2.48)$ & $(-2.64)$ & $(-3.27)$ & $(-2.48)$ & $(-4.55)$ & $(-4.44)$ & $(-3.06)$ & $(-4.63)$ & $(-5.33)$ & $\begin{array}{r}0.270 * * * \\
(-4.98)\end{array}$ & $\begin{array}{r}0.263 * * * \\
(-5.17)\end{array}$ & $(-5.35)$ \\
\hline \multirow[t]{2}{*}{$T_{i t}$} & & -0.0003 & & & & 0.017 & & & & 0.009 & & & & $0.058 * * *$ & & \\
\hline & & $(-0.03)$ & & & & (1.84) & & & & $(0.43)$ & & & & (3.84) & & \\
\hline \multirow[t]{2}{*}{$\inf _{i t \mid s-1} \times \boldsymbol{T}_{i t}$} & & & & $-0.013 * *$ & & & & $-0.018 * * *$ & & & & $-0.055 * * *$ & & & & $-0.037 * * *$ \\
\hline & & & & $(-2.06)$ & & & & $(-4.13)$ & & & & $(-5.28)$ & & & & $(-5.06)$ \\
\hline \multirow[t]{2}{*}{$I T_{i t}$} & & & 0.022 & & & & $0.185 * * *$ & & & & $0.600 * * *$ & & & & $0.523 * * *$ & \\
\hline & & & $(0.46)$ & & & & (5.15) & & & & (6.39) & & & & (9.28) & \\
\hline \multirow[t]{2}{*}{$O i l_{t-1}$} & $0.014 * * *$ & $0.014 * * *$ & $0.014 * * *$ & $0.014 * * *$ & $0.011 * * *$ & $0.011 * * *$ & $0.012 * * *$ & $0.011 * * *$ & $0.008 * * *$ & $0.008 * * *$ & $0.008 * * *$ & $0.009 * * *$ & $0.006 * * *$ & $0.005 * * *$ & $0.006^{* * *}$ & $0.007 * * *$ \\
\hline & (10.14) & (10.12) & (10.04) & (10.00) & (10.04) & (10.08) & (10.79) & (10.10) & (5.81) & (5.57) & (5.74) & (6.44) & (6.41) & (5.46) & (6.92) & $(7.21)$ \\
\hline \multirow{2}{*}{$\inf _{i t \mid s-1}$} & $0.767 * * *$ & $0.767 * * *$ & $0.761 * * *$ & $0.889 * * *$ & $0.628 * * *$ & $0.623 * * *$ & $0.607 * * *$ & $0.804 * * *$ & $0.488 * * *$ & $0.487 * * *$ & $0.438^{* * *}$ & $1.059 * * *$ & $0.379 * * *$ & $0.371 * * *$ & $0.360 * * *$ & $0.772 * * *$ \\
\hline & $(41.00)$ & $(41.03)$ & (39.90) & $(14.31)$ & $(37.88)$ & $(37.91)$ & $(38.38)$ & (17.49) & (17.09) & (16.95) & $(14.80)$ & $(9.56)$ & (18.58) & (18.24) & (18.38) & $(9.53)$ \\
\hline Nºbs & 420 & 420 & 420 & 420 & 350 & 350 & 350 & 350 & 660 & 660 & 660 & 660 & 552 & 552 & 552 & 552 \\
\hline
\end{tabular}

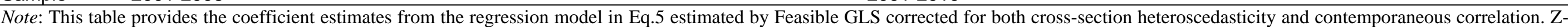

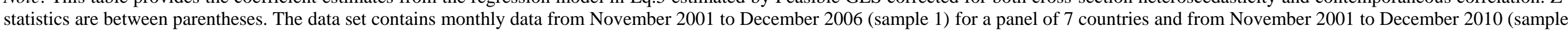

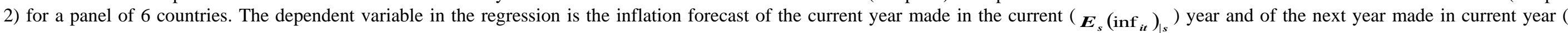

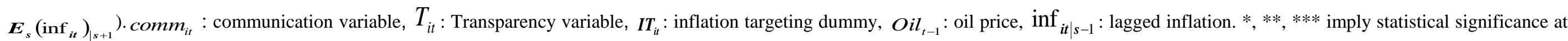
the 10,5 and $1 \%$, respectively. Regressions were run using Stata11. 
Table B.3.1

Transparency and inflation forecasts (continued 1)

\begin{tabular}{|c|c|c|c|c|c|c|c|c|c|c|c|c|c|c|c|c|}
\hline & \multicolumn{4}{|c|}{ Current year } & \multicolumn{4}{|l|}{ Next year } & \multicolumn{4}{|c|}{ Current year } & \multicolumn{4}{|l|}{ Next year } \\
\hline & \multicolumn{4}{|c|}{$E_{s}\left(\inf _{i t}\right)_{\mid s}$} & \multicolumn{4}{|c|}{$\boldsymbol{E}_{s}\left(\inf _{i t}\right)_{\mid s+1}$} & \multicolumn{4}{|c|}{$E_{s}\left(\inf _{i t}\right)_{\mid s}$} & \multicolumn{4}{|c|}{$\boldsymbol{E}_{s}\left(\inf _{i t}\right)_{\mid s+1}$} \\
\hline \multirow{2}{*}{$\alpha$} & $-0.203 * *$ & $-0.406 * * *$ & 0.111 & $-0.591 * * * *$ & 0.012 & $-0.339 * * *$ & $0.481 * * *$ & $-0.276^{* * *}$ & 0.065 & $-0.523 * * *$ & -0.106 & $-1.052 * * *$ & 0.153 & - & $0.326^{* * *}$ & $-0.632 * * *$ \\
\hline & $(-1.99)$ & $(-3.51)$ & $(1.43)$ & $(-6.41)$ & $(0.15)$ & $(-4.55)$ & $(7.82)$ & $(-3.32)$ & $(0.43)$ & $(-3.97)$ & $(-0.78)$ & $(-6.24)$ & $(1.44)$ & $\begin{array}{r}0.302 * * * \\
(-3.50)\end{array}$ & $(3.59)$ & $(-7.02)$ \\
\hline \multirow{2}{*}{ comm $_{i t}$} & $-0.079 *$ & & -0.070 & $-0.128 * * *$ & $-0.066 * *$ & $-0.066 * *$ & $-0.083 * *$ & $-0.118 * * *$ & $-0.095 * *$ & $-0.101 * * *$ & $-0.265^{* * *}$ & $-0.206 * * *$ & $-0.093 * * *$ & - & - & $-0.072 * *$ \\
\hline & $(-1.87)$ & & $(-1.60)$ & $(-2.85)$ & $(-2.04)$ & $(-2.29)$ & $(-2.55)$ & $(-3.06)$ & $(-2.31)$ & $(-2.40)$ & $(-3.39)$ & $(-2.75)$ & $(-2.68)$ & $\begin{array}{r}0.085 * * * \\
(-2.61)\end{array}$ & $\begin{array}{r}0.091 * * * \\
(-2.53)\end{array}$ & $(-2.33)$ \\
\hline \multirow{2}{*}{$T_{i t}$} & $0.030 * * *$ & $-0.022 *$ & & & $0.053 * * *$ & $0.009 *$ & & & 0.013 & $-0.024 *$ & & & $0.047 * * *$ & $-0.021 * *$ & & \\
\hline & $(3.14)$ & $(-1.83)$ & & & $(8.56)$ & $(1.71)$ & & & $(1.18)$ & $(-1.78)$ & & & $(5.78)$ & $(-2.24)$ & & \\
\hline \multirow[t]{2}{*}{$I T_{i t}$} & & & $0.234 * * *$ & 0.030 & & & $0.375 * * *$ & $0.145 * * *$ & & & $0.607 * * *$ & $0.501 * * *$ & & & $0.458 * * *$ & $0.368 * * *$ \\
\hline & & & $(5.06)$ & $(0.67)$ & & & (11.74) & (4.19) & & & $(6.61)$ & $(5.61)$ & & & $(15.85)$ & (12.26) \\
\hline \multirow[t]{2}{*}{ Outgap $_{i t \mid s-1}$} & $0.171 * * *$ & & $0.205^{* * *}$ & & $0.194 * * *$ & & $0.219 * * *$ & & $0.085 * * *$ & & $0.040^{*}$ & & 0.011 & & $0.034 * *$ & \\
\hline & (9.94) & & (10.87) & & (13.95) & & (14.85) & & $(5.40)$ & & (1.72) & & $(0.94)$ & & $(2.35)$ & \\
\hline \multirow[t]{2}{*}{ Unemp $_{i t \mid s-1}$} & & $0.072 * * *$ & & $0.066 * * *$ & & $0.083 * * *$ & & $0.066 * * *$ & & $0.112 * * *$ & & $0.158 * * *$ & & $0.179 * * *$ & & $0.156^{* * *}$ \\
\hline & & (4.65) & & (4.29) & & (7.77) & & (5.26) & & (6.38) & & (7.12) & & (13.57) & & (18.22) \\
\hline \multirow[t]{2}{*}{$O i l_{t-1}$} & $0.009 * * *$ & $0.013 * * *$ & $0.007 * * *$ & $0.013 * * *$ & $0.006^{* * *}$ & $0.011 * * *$ & $0.004 * * *$ & $0.011 * * *$ & $0.006 * * *$ & $0.011 * * *$ & $0.010 * * *$ & $0.011 * * *$ & $0.005 * * *$ & $0.008^{* * *}$ & $0.006 * * *$ & $0.008 * * *$ \\
\hline & (6.97) & (10.46) & $(5.44)$ & (10.27) & $(6.50)$ & (13.09) & (4.61) & (10.66) & $(3.96)$ & $(6.91)$ & $(6.85)$ & $(8.78)$ & $(4.57)$ & $(8.41)$ & $(5.57)$ & $(8.37)$ \\
\hline \multirow{2}{*}{$\inf _{i t \mid s-1}$} & $0.630 * * *$ & $0.745^{* * *}$ & $0.577 * * *$ & $0.743 * * *$ & $0.456 * * *$ & $0.563 * * *$ & $0.411 * * *$ & $0.585^{* * * *}$ & $0.566^{* * * *}$ & $0.649 * * *$ & $0.402 * * *$ & $0.425 * * *$ & $0.408 * * *$ & $0.442 * * *$ & $0.365^{* * * *}$ & $0.415^{* * *}$ \\
\hline & (28.34) & $(38.30)$ & $(24.53)$ & $(37.40)$ & (26.48) & (41.66) & (23.65) & $(35.85)$ & (19.39) & $(28.22)$ & (11.17) & (15.20) & (19.38) & $(28.84$ & $(17.26)$ & (24.15) \\
\hline$N^{\circ}$ obs & 420 & 420 & 420 & 420 & 350 & 350 & 350 & 350 & 654 & 654 & 654 & 654 & 546 & 546 & 546 & 546 \\
\hline
\end{tabular}

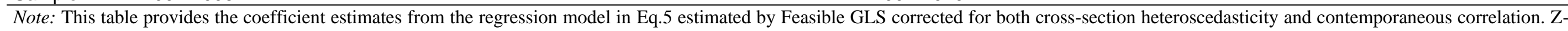

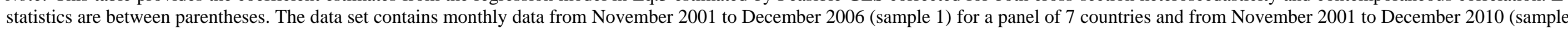

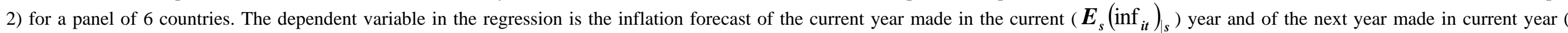

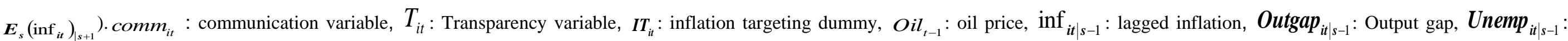
unemployment rate. $* * *, * * *$ imply statistical significance at 10,5 and $1 \%$, respectively. Regressions were run using Stata11. 


\section{Table B.3.1}

Transparency and inflation forecasts (continued 2)

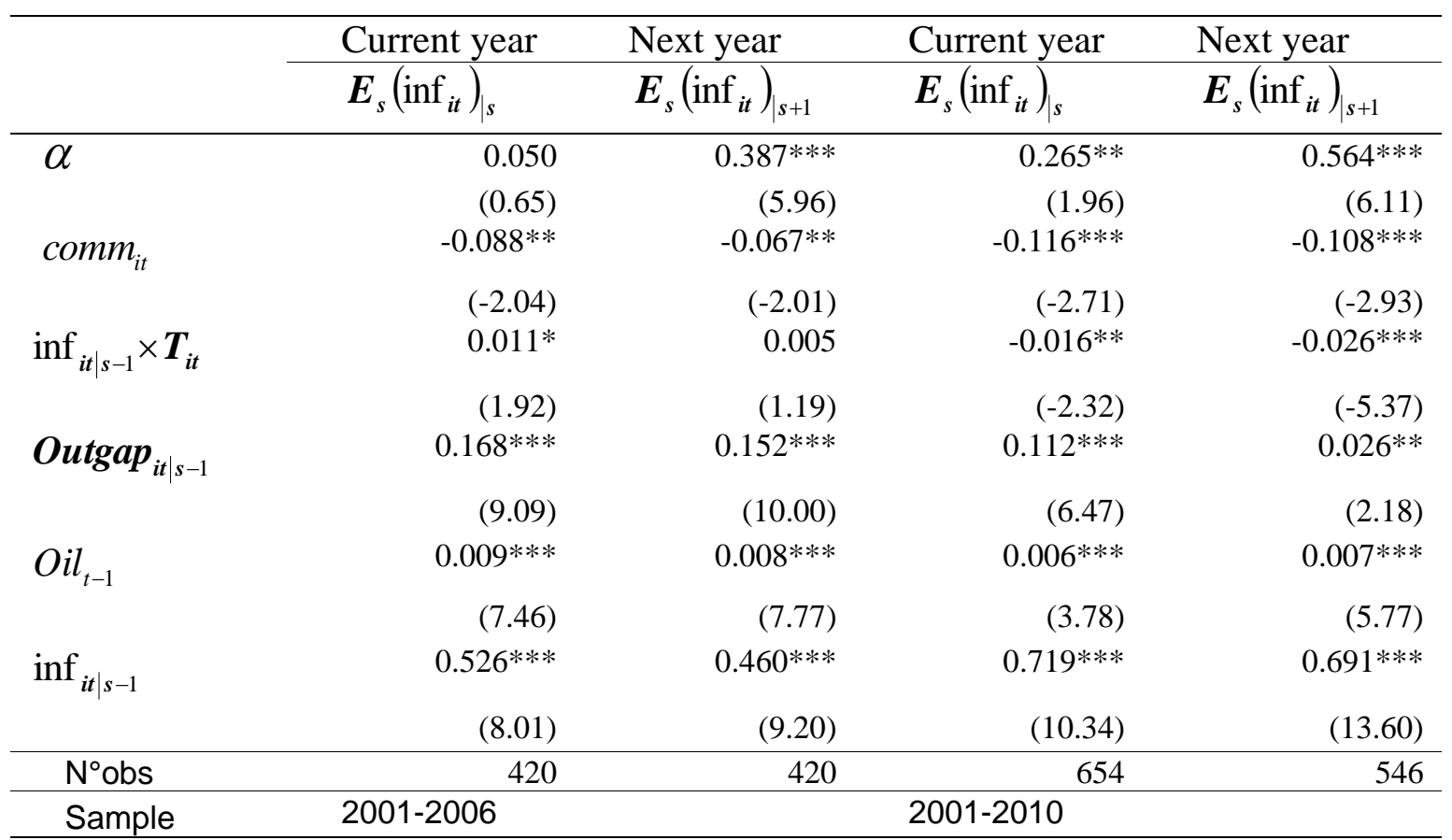

Note: This table provides the coefficient estimates from the regression model in Eq.5 estimated by Feasible GLS corrected for both cross-section heteroscedasticity and contemporaneous correlation. Z-statistics are between parentheses. The data set contains monthly data from November 2001 to December 2006 (sample 1) for a panel of 7 countries and from November 2001 to December 2010 (sample 2) for a panel of 6 countries. The dependent variable in the regression is the inflation forecast of the current year made in the current $\left(\boldsymbol{E}_{s}\left(\inf _{i t}\right)_{\mid s}\right)$ year and of the next year made in current year $\left(\boldsymbol{E}_{s}\left(\inf _{i t}\right)_{\mid s+1}\right) \cdot \operatorname{comm}_{i t}$ : communication variable, $T_{i t}$ : Transparency variable, $\boldsymbol{I} \boldsymbol{T}_{i t}$ : inflation targeting dummy, $O i l_{t-1}$ : oil price, inf ${ }_{i t \mid s-1}$ : lagged inflation, Outgap $\left.\right|_{i t \mid s-1}$ : Output gap. *,**,*** imply statistical significance at 10, 5 and $1 \%$, respectively.

Regressions were run using Stata11. 


\section{Table B.3.2}

Transparency and RGDP forecasts

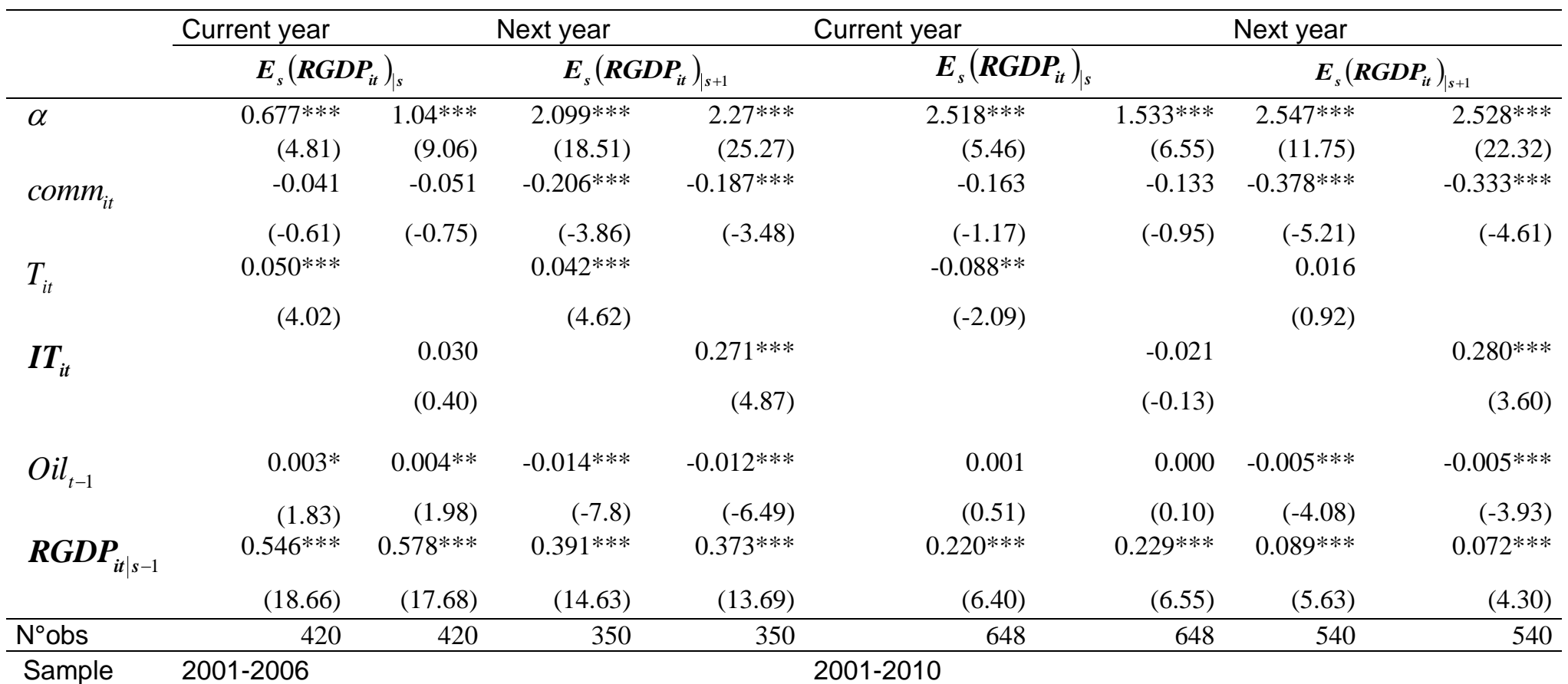

Note: This table provides the coefficient estimates from the regression model in Eq.5 estimated by Feasible GLS corrected for both cross-section heteroscedasticity and contemporaneous correlation. Z-statistics are between parentheses. The data set contains monthly data from November 2001 to December 2006 (sample 1) for a panel of 7 countries and from November 2001 to December 2006 (sample 2) for a panel of 6 countries. The dependent variable in the regression is the RGDP forecast of the current year made in the current year $\left(\boldsymbol{E}_{s}\left(\boldsymbol{R} \boldsymbol{G D P} \boldsymbol{P}_{i t}\right)_{s}\right)$ and of the next year made in current year $\left(\boldsymbol{E}_{s}\left(\boldsymbol{R} \boldsymbol{G D P} \boldsymbol{P}_{i t}\right)_{\mid s+1}\right)$. comm $i t$ : communication variable, $T_{i t}$ : Transparency variable, $\boldsymbol{I T}_{i t}$ : inflation targeting dummy, Oil ${ }_{t-1}$ : oil price, $\boldsymbol{R G}_{\boldsymbol{D}} \boldsymbol{P}_{\boldsymbol{i t | s - 1}}$ : lagged actual RGDP. *, **,*** imply statistical significance at 10,5 and $1 \%$, respectively. Regressions were run using Stata11. 
Table B.3.3

Transparency and CC/GDP forecasts

\begin{tabular}{|c|c|c|c|c|c|c|c|c|}
\hline \multirow[b]{3}{*}{$\alpha$} & \multirow{2}{*}{\multicolumn{2}{|c|}{$\begin{array}{l}\text { Current year } \\
\boldsymbol{E}_{s}\left(\boldsymbol{C} \boldsymbol{C} / \boldsymbol{G D P} \boldsymbol{P}_{i t}\right)_{\mid s}\end{array}$}} & \multirow{2}{*}{\multicolumn{2}{|c|}{$\frac{\text { Next year }}{\boldsymbol{E}_{\boldsymbol{s}}\left(\boldsymbol{C} \boldsymbol{C} / \boldsymbol{G} \boldsymbol{D} \boldsymbol{P}_{i t}\right)_{\mid s+1}}$}} & \multirow{2}{*}{\multicolumn{2}{|c|}{$\begin{array}{l}\text { Current year } \\
\qquad \boldsymbol{E}_{s}\left(\boldsymbol{C} \boldsymbol{C} / \boldsymbol{G D P} \boldsymbol{P}_{i t}\right)_{\mid s}\end{array}$}} & \multirow{2}{*}{\multicolumn{2}{|c|}{$\begin{array}{l}\text { Next year } \\
\qquad \boldsymbol{E}_{s}\left(\boldsymbol{C} \boldsymbol{C} / \boldsymbol{G} \boldsymbol{D P} \boldsymbol{P}_{i t}\right)_{\mid s+1}\end{array}$}} \\
\hline & & & & & & & & \\
\hline & $\begin{array}{l}-0.229 \\
(-1.36)\end{array}$ & $\begin{array}{r}-0.226^{*} \\
(-1.89)\end{array}$ & $\begin{array}{r}0.0002 \\
(0.00)\end{array}$ & $\begin{array}{r}0.086 \\
(0.64)\end{array}$ & $\begin{array}{r}0.745 * * * \\
(2.52)\end{array}$ & $\begin{array}{r}-0.818 * * * \\
(-7.17)\end{array}$ & $\begin{array}{r}1.002 * * * \\
(2.88)\end{array}$ & $\begin{array}{r}-0.909 * * * \\
(-8.26)\end{array}$ \\
\hline comm $_{i t}$ & $\begin{array}{r}0.195 * * * \\
(2.67)\end{array}$ & $\begin{array}{r}0.279 * * * \\
(3.70)\end{array}$ & $\begin{array}{r}0.262 * * * \\
(3.27)\end{array}$ & $\begin{array}{r}0.300 * * * \\
(3.60)\end{array}$ & $\begin{array}{r}0.175^{*} \\
(1.89)\end{array}$ & $\begin{array}{r}0.349 * * * \\
(4.11)\end{array}$ & $\begin{array}{r}0.274 * * \\
(2.38)\end{array}$ & $\begin{array}{r}0.513 * * * \\
(5.54)\end{array}$ \\
\hline$T_{i t}$ & $\begin{array}{l}0.029 * \\
(1.86)\end{array}$ & & $\begin{array}{r}0.036^{* *} \\
(2.29)\end{array}$ & 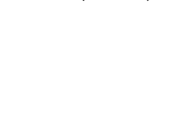 & $\begin{array}{r}-0.160 * * * \\
(-6.03)\end{array}$ & & $\begin{array}{r}-0.176^{* * *} \\
(-5.91)\end{array}$ & \\
\hline$I T_{i t}$ & & $\begin{array}{r}0.605^{* * * *} \\
(7.14)\end{array}$ & & $\begin{array}{r}0.607 * * * \\
(6.49)\end{array}$ & & $\begin{array}{r}-0.152 * \\
(-1.93)\end{array}$ & & $\begin{array}{r}0.160 * \\
(1.70)\end{array}$ \\
\hline$O i l_{t-1}$ & $\begin{array}{r}0.008 * * * \\
(3.19)\end{array}$ & $\begin{array}{r}0.012 * * * \\
(4.60)\end{array}$ & $\begin{array}{r}0.004 \\
(1.24)\end{array}$ & $\begin{array}{r}0.007 * * * \\
(2.32)\end{array}$ & $\begin{array}{r}0.010 * * * \\
(6.59)\end{array}$ & $\begin{array}{r}0.008 * * * \\
(5.58)\end{array}$ & $\begin{array}{r}0.009 * * * \\
(5.18)\end{array}$ & $\begin{array}{r}0.008 * * * \\
(6.22)\end{array}$ \\
\hline $\boldsymbol{R G D P} \boldsymbol{P}_{i t \mid s-1}$ & $\begin{array}{r}-0.323 * * * \\
(-7.85)\end{array}$ & $\begin{array}{r}-0.279 * * * \\
(-9.33)\end{array}$ & $\begin{array}{r}-0.344 * * * \\
(-7.19)\end{array}$ & $\begin{array}{r}-0.455 * * * \\
(-8.68)\end{array}$ & & & & \\
\hline $\boldsymbol{C C} / \boldsymbol{G D P} \boldsymbol{P}_{i t \mid s-1}$ & $\begin{array}{r}0.917 * * * \\
(89.57)\end{array}$ & $\begin{array}{r}0.924 * * * \\
(94.44)\end{array}$ & $\begin{array}{r}0.867 * * * \\
(68.71)\end{array}$ & $\begin{array}{r}0.872 * * * \\
(75.69)\end{array}$ & $\begin{array}{r}0.978 * * * \\
(100.06)\end{array}$ & $\begin{array}{r}0.954 * * * \\
(11.30)\end{array}$ & $\begin{array}{r}0.952 * * * \\
(78.26)\end{array}$ & $\begin{array}{r}0.942 * * * \\
(97.38)\end{array}$ \\
\hline $\mathrm{N}^{\circ} \mathrm{obs}$ & 420 & 420 & 350 & 350 & 660 & 660 & 552 & 552 \\
\hline
\end{tabular}

Note: This table provides the coefficient estimates from the regression model in Eq.5 estimated by Feasible GLS corrected for both cross-section heteroscedasticity and contemporaneous correlation. Z-statistics are between parentheses. The data set contains monthly data from November 2001 to December 2006 (sample 1) for a panel of 7 countries and from November 2001 to December 2010 (sample 2) for a panel of 6 countries. The dependent variable in the regression is the current account as a \% of GDP forecast of the current year made in the current year $\left(\boldsymbol{E}_{\boldsymbol{s}}\left(\boldsymbol{C C} / \boldsymbol{G D P} \boldsymbol{P}_{i t}\right)_{\mid s}\right)$ and of the next year made in current year $\left(E_{s}\left(C C / G D P_{i t}\right)_{s+1}\right) \cdot \operatorname{comm}_{i t}:$ communication variable, $T_{i t}$ : Transparency variable, $\boldsymbol{I T}_{i t}$ : inflation targeting dummy, $O i l_{t-1}:$ oil price, $\boldsymbol{R G D P}_{i t \mid s-1}$ : lagged actual RGDP, $\boldsymbol{C C} / \boldsymbol{G D} \boldsymbol{P}_{i t \mid s-1}$ : lagged actual current account. *, **, *** imply statistical significance at 10,5 and $1 \%$, respectively. Regressions were run using Stata11. 


\section{Table B.4.1}

Transparency and inflation forecast accuracy

\begin{tabular}{|c|c|c|c|c|c|c|c|c|c|c|c|c|}
\hline \multirow{3}{*}{$\begin{array}{l}\text { Absolute forecast error } \\
\alpha\end{array}$} & \multicolumn{3}{|c|}{ Current year } & \multicolumn{3}{|l|}{ Next year } & \multicolumn{3}{|c|}{ Current year } & \multicolumn{3}{|l|}{ Next year } \\
\hline & \multicolumn{3}{|c|}{$\left|E_{s}\left(\mathbf{i n f}_{i t}\right)_{\mid s}-\mathbf{i n f}_{\mid s}\right|$} & \multicolumn{3}{|c|}{$\left|E_{s}\left(\mathbf{i n f}_{i t}\right)_{\mid s+1}-\inf _{\mid s+1}\right|$} & \multicolumn{3}{|c|}{$\left|E_{s}\left(\mathbf{i n f}_{i t}\right)_{\mid s}-\inf _{\mid s}\right|$} & \multicolumn{3}{|c|}{$\left|E_{s}\left(\mathbf{i n f}_{i t}\right)_{\mid s+1}-\mathbf{i n f} \mathbf{f}_{\mid s+1}\right|$} \\
\hline & $0.081 * * *$ & $0.054^{*}$ & $0.075 * * *$ & $0.024 * * *$ & 0.010 & $0.021 * *$ & $0.075 * * *$ & -0.001 & 0.095 & $0.022 * * *$ & 0.012 & 0.015 \\
\hline & (5.48) & $(1.70)$ & (4.34) & (2.85) & $(0.57)$ & (2.10) & (4.94) & $(-0.02)$ & $(3.81)$ & (2.13) & $(0.36)$ & $(0.77)$ \\
\hline \multirow[t]{2}{*}{ comm $_{i t}$} & -0.007 & -0.007 & -0.005 & -0.004 & -0.003 & -0.003 & 0.010 & 0.012 & 0.008 & 0.004 & 0.005 & 0.004 \\
\hline & $(-0.56)$ & $(-0.55)$ & $(-0.40)$ & $(-0.46)$ & $(-0.39)$ & $(-0.32)$ & $(0.56)$ & $(0.69)$ & $(0.45)$ & $(0.33)$ & $(0.36)$ & $(0.33)$ \\
\hline \multirow[t]{2}{*}{$T_{i t}$} & & 0.003 & & & 0.002 & & & 0.007 & & & 0.001 & \\
\hline & & $(1.00)$ & & & $(0.99)$ & & & $(1.45)$ & & & $(0.29)$ & \\
\hline \multirow[t]{2}{*}{$I T_{i t}$} & & & 0.01 & & & 0.005 & & & -0.022 & & & 0.007 \\
\hline & & & $(0.76)$ & & & $(0.55)$ & & & $(-1.01)$ & & & $(0.40)$ \\
\hline \multirow[t]{2}{*}{$\left|\Delta o i l_{t-1}\right|$} & $-0.007 * * *$ & $-0.007 * * *$ & $-0.007 * * *$ & $-0.003 *$ & $-0.003 * *$ & $-0.003 *$ & 0.002 & 0.002 & 0.002 & $-0.007 * * *$ & $-0.007 * * *$ & $-0.007 * * *$ \\
\hline & $(-2.43)$ & $(-2.50)$ & $(-2.42)$ & $(-1.94)$ & $(-1.98)$ & $(-1.93)$ & (1.34) & (1.21) & (1.34) & $(-4.76)$ & $(-4.74)$ & $(-4.78)$ \\
\hline \multirow{2}{*}{$\left|E_{s}\left(\mathbf{i n f}_{i t-1}\right)_{\mid s}-\mathbf{i n f}_{\mid s}\right|$} & $0.802 * * *$ & $0.796^{* * *}$ & $0.800 * * *$ & & & & $0.668 * * *$ & $0.662 * * *$ & $0.665 * * *$ & & & \\
\hline & $(27.91)$ & $(27.35)$ & (27.67) & & & & $(22.79)$ & $(22.43)$ & $(22.62)$ & & & \\
\hline \multirow{2}{*}{$\left|E_{s}\left(\inf _{i t-1}\right)_{\mid s+1}-\inf _{\mid s+1}\right|$} & & & & $0.953 * * *$ & $0.945^{* * *}$ & $0.952 * * *$ & & & & $0.992 * * *$ & $0.991 * * *$ & $0.992 * * *$ \\
\hline & & & & (98.53) & (90.50) & (98.31) & & & & $(104.31)$ & (102.06) & (103.08) \\
\hline $\mathrm{N}^{\circ} \mathrm{obs}$ & 420 & 420 & 420 & 315 & 315 & 315 & 648 & 648 & 648 & 486 & 486 & 486 \\
\hline Sample & $2001-2006$ & & & & & & 2001-201 & & & & & \\
\hline
\end{tabular}

Note: This table provides the coefficient estimates from the regression model in Eq.6 estimated by Feasible GLS corrected for both cross-section heteroscedasticity and contemporaneous correlation. Z-statistics are between parentheses. The data set contains monthly data from November 2001 to December 2006 (sample 1 ) for a panel of 7 countries and from November 2001 to December 2010 (sample 2) for a panel of 6 countries. The dependent variable in the regression is the absolute forecast error of inflation

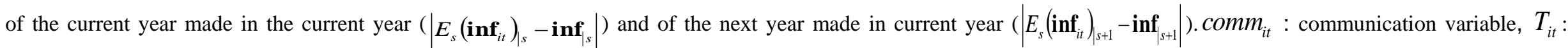
Transparency variable, $\boldsymbol{I T} \boldsymbol{T}_{i t}$ : inflation targeting dummy, $\left|\Delta o i l_{t-1}\right|:$ lagged oil price. $*{ }^{* *}, * * *$ imply statistical significance at 10,5 and $1 \%$, respectively. Regressions were run using Stata11. 
Table B.4.2Transparency and RGDP forecast accuracy

\begin{tabular}{|c|c|c|c|c|c|c|c|c|c|c|c|c|}
\hline \multirow{3}{*}{$\begin{array}{l}\text { Absolute Forecast error } \\
\alpha\end{array}$} & \multicolumn{3}{|c|}{ Current year } & \multicolumn{3}{|l|}{ Next year } & \multicolumn{3}{|c|}{ Current year } & \multicolumn{3}{|l|}{ Next year } \\
\hline & \multicolumn{3}{|c|}{$\left|E_{s}\left(R G D P_{i t}\right)_{\mid s}-R G D P_{\mid s}\right|$} & \multicolumn{3}{|c|}{$E_{s}\left(R G D P_{i t}\right)_{\mid s+1}-R G D P_{\mid s+1}$} & \multicolumn{3}{|c|}{$\left|E_{s}\left(R G D P_{i t}\right)_{\mid s}-R G D P_{\mid s}\right|$} & \multicolumn{3}{|c|}{$\left|E_{s}\left(R G D P_{i t}\right)_{\mid s+1}-R G D P_{\mid s+1}\right|$} \\
\hline & $0.104 * * *$ & $0.304 * * *$ & $0.23 * * *$ & $0.059 *$ & 0.021 & $0.029 * *$ & $0.076 * * *$ & -0.149 & $0.141 * *$ & $0.041 * * *$ & 0.017 & 0.022 \\
\hline & (4.61) & (4.78) & (6.53) & $(1.85)$ & $(1.34)$ & (2.17) & (3.27 & $(-1.49)$ & (2.39) & (3.20) & $(0.41)$ & (1.14) \\
\hline \multirow[t]{2}{*}{ comm $_{i t}$} & 0.019 & -0.005 & -0.007 & -0.001 & -0.010 & -0.010 & 0.006 & 0.012 & 0.006 & -0.018 & -0.017 & -0.017 \\
\hline & $(0.98)$ & $(-0.23)$ & $(-0.30)$ & $(-0.83)$ & $(-0.76)$ & $(-0.78)$ & $(0.257)$ & $(0.48)$ & $(0.24)$ & $(-1.15)$ & $(-1.06)$ & $(-1.03)$ \\
\hline \multirow[t]{2}{*}{$T_{i t}$} & & $0.013 * * *$ & & -0.003 & & & & $0.023 * *$ & & & 0.002 & \\
\hline & & $(-2.35)$ & & $(-1.04)$ & & & & $(2.30)$ & & & $(0.55)$ & \\
\hline \multirow[t]{2}{*}{$I T_{i t}$} & & & $0.079 * * *$ & & 0.014 & & & & -0.004 & & & \\
\hline & & & $(-2.85)$ & & $(1.10)$ & & & & $(-0.14)$ & & & $(1.21)$ \\
\hline \multirow[t]{2}{*}{$\left|\Delta o_{t-1}\right|$} & -0.006 & -0.003 & -0.004 & -0.000 & -0.000 & -0.000 & $0.008 * * *$ & $0.006 * * *$ & $0.008 * * *$ & $0.010^{*} * *$ & $-0.010 * * *$ & $-0.010 * * *$ \\
\hline & $(-1.44)$ & $(-0.67)$ & $(-0.75)$ & $(-0.02)$ & $(-0.03)$ & $(-0.02)$ & (2.75) & (2.44) & $(2.75$ & $(-5.80)$ & $(-5.75)$ & $(5.82)$ \\
\hline \multirow{2}{*}{$\left|E_{s}\left(R G D P_{i t-1}\right)_{\mid s}-R G D P_{\mid s}\right|$} & $0.834 * * *$ & $0.715^{* * *}$ & $0.707 * * *$ & & & & $0.853 * * *$ & $0.840 * * *$ & $0.853 * * *$ & & & \\
\hline & (31.30) & (21.83) & $(21.56)$ & & & & $(42.22)$ & (40.00) & $(42.22)$ & & & \\
\hline \multirow{2}{*}{$\left|E_{s}\left(R G D P_{i t-1}\right)_{s+1}-R G D P_{\mid s+1}\right|$} & & & & $0.951 * * *$ & $0.954 * *$ & $0.954 * * *$ & & & & $0.975 * * *$ & $0.975 * * *$ & $0.975 * * *$ \\
\hline & & & & $(91.08)$ & $(92.52)$ & $(93.60)$ & & & & (194.67) & (184.10) & (194.81) \\
\hline Noobs & 420 & 420 & 420 & 315 & 315 & 315 & 648 & 648 & 648 & 486 & 486 & 486 \\
\hline Sample & $2001-200$ & & & & & & 2001-20 & & & & & \\
\hline
\end{tabular}

Note: This table provides the coefficient estimates from the regression model in Eq.6 estimated by Feasible GLS corrected for both cross-section heteroscedasticity and contemporaneous correlation. Z-statistics are between parentheses. The data set contains monthly data from November 2001 to December 2006 (sample 1 ) for a panel of 7 countries and from November 2001 to December 2010 (sample 2) for a panel of 6 countries. The dependent variable in the regression is the absolute forecast error of RGDP of the current year made in the current year $\left(\left|E_{s}\left(R G D P_{i t}\right)_{\mid s}-R G D P_{\mid s}\right|\right)$ and of the next year made in current year $\left(\left|E_{s}\left(R G D P_{i t}\right)_{\mid s+1}-R G D P_{\mid s+1}\right|\right) \cdot c o m m_{i t}:$ communication variable, $T_{i t}$ : Transparency variable, $I T_{i t}$ : inflation targeting dummy, $\left|\Delta o i l_{t-1}\right|$ : lagged oil price. *, **, *** imply statistical significance at 10,5 and $1 \%$, respectively. Regressions were run using Stata11. 


\section{Table B.4.3}

Transparency and CC/GDP forecast accuracy

\begin{tabular}{|c|c|c|c|c|c|c|c|c|c|c|}
\hline \multirow{3}{*}{$\begin{array}{l}\text { Absolute forecast error } \\
\alpha \alpha\end{array}$} & \multicolumn{3}{|c|}{ Current year } & \multicolumn{3}{|c|}{ Next year } & \multicolumn{2}{|c|}{ Current year } & \multicolumn{2}{|l|}{ Next year } \\
\hline & \multicolumn{3}{|c|}{$\left|E_{s}\left(C C / G D P_{i t}\right)_{\mid s}-C C / G D P_{\mid s}\right|$} & \multicolumn{3}{|c|}{$\left|E_{s}\left(C C / G D P_{i t}\right)_{\mid s+1}-C C / G D P_{\mid s+1}\right|$} & \multicolumn{2}{|c|}{$\left|E_{s}\left(C C / G D P_{i t}\right)_{\mid s}-C C / G D P_{\mid s}\right|$} & \multicolumn{2}{|c|}{$\mid E_{s}\left(C C / G D P_{i t}\right)_{\mid s+1}-C C / G D P_{\mid s+1}$} \\
\hline & $0.084 * * *$ & 0.044 & $0.085 * * *$ & 0.037 & 0.094 & 0.038 & -0.018 & $0.054 * * *$ & 0.025 & -0.006 \\
\hline & (3.89) & $(0.63)$ & (3.85) & $(1.26)$ & $(1.63)$ & $(1.23)$ & $(-0.19)$ & $(2.88)$ & $(0.28)$ & $(-0.21)$ \\
\hline \multirow{2}{*}{ comm $_{i t}$} & $-0.058 * * *$ & $-0.059 * * *$ & $-0.057 * * *$ & -0.037 & -0.038 & -0.037 & -0.043 & $-0.050^{*}$ & 0.011 & 0.009 \\
\hline & $(-3.08)$ & $(-3.14)$ & $(-3.06)$ & $(-1.46)$ & $(-1.52)$ & $(-1.41)$ & $(-1.59)$ & $(-1.90)$ & $(0.31)$ & $(0.27)$ \\
\hline \multirow[t]{2}{*}{$T_{i t}$} & & 0.004 & & & -0.006 & & 0.008 & & -0.001 & \\
\hline & & $(0.61)$ & & & $(-1.14)$ & & $(0.86)$ & & $(-0.17)$ & \\
\hline \multirow[t]{2}{*}{$\boldsymbol{I T}_{i t}$} & & & -0.009 & & & -0.002 & & $0.042^{*}$ & & 0.034 \\
\hline & & & $(-0.31)$ & & & $(-0.07)$ & & $(1.60)$ & & $(0.92)$ \\
\hline \multirow[t]{2}{*}{$\left|\Delta o i l_{t-1}\right|$} & -0.005 & -0.004 & -0.005 & -0.003 & -0.003 & -0.001 & -0.003 & -0.003 & $-0.006 * *$ & $-0.005^{* *}$ \\
\hline & $(-0.95)$ & $(-0.88)$ & $(-0.97)$ & $(-0.62)$ & $(-0.53)$ & $(-0.62)$ & $(-1.44)$ & $(-1.31)$ & $(-1.99)$ & $(-1.96)$ \\
\hline \multirow{2}{*}{$\left|E_{s}\left(C C / G D P_{i t-1}\right)_{\mid s}-C C / G D P_{|s|}\right|$} & $0.911 * * *$ & $0.809 * * *$ & $0.911 * * *$ & & & & $0.932 * * *$ & $0.927 * * *$ & & \\
\hline & $(46.24)$ & $(45.74)$ & $(46.23)$ & & & & $(62.84)$ & $(61.46)$ & & \\
\hline \multirow{2}{*}{$\left|E_{s}\left(C C / G D P_{i t-1}\right)_{\mid s+1}-C C / G D P_{\mid s+1}\right|$} & & & & $0.972 * * *$ & $0.976^{* * *}$ & $0.972 * * *$ & & & $0.979 * * *$ & $0.976 * * *$ \\
\hline & & & & $(82.07)$ & $(78.95)$ & $(73.68)$ & & & $(101.32)$ & $(95.12)$ \\
\hline Nºbs & 420 & 420 & 420 & 315 & 315 & 315 & 648 & 648 & 486 & 486 \\
\hline Sample & $2001-2006$ & & & & & & $2001-2010$ & & & \\
\hline $\begin{array}{l}\text { Note: This table provides the coefficie } \\
\text { correlation. Z-statistics are between pa } \\
\text { to December } 2010 \text { (sample } 2 \text { ) for a par }\end{array}$ & $\begin{array}{l}\text { estimates frol } \\
\text { entheses. The d } \\
1 \text { of } 6 \text { countries }\end{array}$ & $\begin{array}{l}\text { dhe regress } \\
\text { data set contai } \\
\text { s. The depend }\end{array}$ & $\begin{array}{l}\text { on model in } \\
\text { is monthly di } \\
\text { ent variable i }\end{array}$ & $\begin{array}{l}\text { Eq.6 estimat } \\
\text { lata from Nov } \\
\text { in the regress }\end{array}$ & $\begin{array}{l}\text { ted by Feasib } \\
\text { vember } 2001 \\
\text { ion is the abs }\end{array}$ & $\begin{array}{l}\text { GLS corre } \\
\text { December } \\
\text { ute forecast }\end{array}$ & $\begin{array}{l}\text { ected for both cros } \\
2006 \text { (sample } 1 \text { ) f } \\
\text { t error of the curre }\end{array}$ & $\begin{array}{l}\text { tion heteros } \\
\text { anel of } 7 \mathrm{co} \\
\text { count as a \% }\end{array}$ & $\begin{array}{l}\text { scedasticity and } \\
\text { ountries and frol } \\
\% \text { of GDP of the }\end{array}$ & $\begin{array}{l}\text { oraneous } \\
\text { ber } 2001 \\
\text { ear made }\end{array}$ \\
\hline
\end{tabular}


Table B.5

Alternative estimations: Economic Transparency and inflation forecast accuracy

\begin{tabular}{|c|c|c|c|c|c|c|c|}
\hline \multirow[t]{2}{*}{ Absolute forecast error } & \multicolumn{2}{|l|}{ Current year } & \multicolumn{2}{|l|}{ Next year } & \multirow[t]{2}{*}{ Inflation } & Current year & Next year \\
\hline & $\mid E_{s}\left(\mathbf{i n f} \mathbf{f}_{i t}\right.$ & $\mathbf{n f}_{|s|}$ & $\mid E_{s}\left(\text { inf }_{i t}\right)_{\mid s+}$ & $-\mathbf{i n f} \mathbf{f}_{\mid s+1} \mid$ & & $E_{s}\left(\inf _{i t}\right)_{\mid s}$ & $E_{s}\left(\inf _{i t}\right)_{\mid s+1}$ \\
\hline \multirow[t]{2}{*}{$\alpha$} & 1.848 & 1.049 & -1.108 & -0.663 & $\alpha$ & $0.837 * * *$ & $0.584^{* * *}$ \\
\hline & $(1.46)$ & $(1.38)$ & $(-0.95)$ & $(-1.02)$ & & (4.16) & (3.80) \\
\hline \multirow[t]{2}{*}{$\hat{T}_{i t}$} & -0.164 & & 0.109 & & comm $_{i t}$ & $-0.372 * * *$ & $-0.289 * * *$ \\
\hline & $(-1.37)$ & & $(0.99)$ & & & $(-4.89)$ & $(-5.26)$ \\
\hline \multirow[t]{2}{*}{$\hat{T}_{i t}(e c o)$} & & -0.378 & & 0.287 & $T_{i t}($ eco $)$ & $-0.329 * * *$ & 0.066 \\
\hline & & $(-1.23)$ & & $(1.10)$ & & $(-4.15)$ & $(1.13)$ \\
\hline \multirow[t]{2}{*}{$\mid \Delta$ oil $_{t-1} \mid$} & 0.007 & 0.006 & $-0.017 * * *$ & $-0.017 * * *$ & $O i l_{t-1}$ & $0.014 * * *$ & $0.007 * * *$ \\
\hline & (1.27) & $(0.256)$ & $(-3.06)$ & $(-3.21)$ & & $(9.35)$ & (6.58) \\
\hline \multirow[t]{2}{*}{$\left|E_{s}\left(\inf _{i t-1}\right)_{\mid s}-\inf _{\mid s}\right|$} & $0.609 * * *$ & $0.581 * * *$ & & & $\inf _{i t \mid s-1}$ & $0.509 * * *$ & $0.382 * * *$ \\
\hline & $(16.05)$ & (16.07) & & & & $(18.59)$ & $(18.64)$ \\
\hline \multirow{2}{*}{$\left|E_{s}\left(\mathbf{i n f}_{i t-1}\right)_{\mid s+1}-\inf _{\mid s+1}\right|$} & & & $0.992 * * *$ & $0.999 * * *$ & & & \\
\hline & & & $(65.86)$ & $(56.68)$ & & & \\
\hline Nºbs & 648 & 648 & 486 & 486 & $\mathrm{~N}^{\circ}$ obs & 654 & 546 \\
\hline Sample & $2001-2010$ & & & & Sample & $2001-2010$ & \\
\hline
\end{tabular}

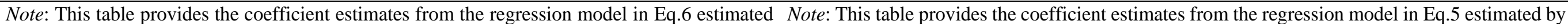

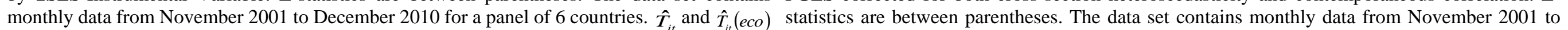

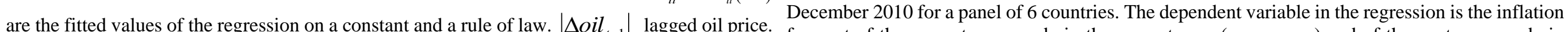
The dependent variable in the regression is the absolute forecast error of inflation of the current year made in the current year $\left(\mid E_{s}\left(\text { inf }_{i t}\right)_{s}-\mathbf{i n f}_{\mid s} \mid\right)$ and of the next year made in current year $\left.\mid E_{s}\left(\text { inf }_{i t}\right)_{\mid s+1}-\mathbf{i n f}_{\mid s+1} \mid\right)^{*}, * *, * * *$ imply statistical significance at 10,5 and $1 \%$, respectively forecast of the current year made in the current year $\left(\boldsymbol{E}_{s}\left(\inf _{i t}\right)_{s}\right)$ and of the next year made in Regressions were run using Stata11. 
Table B.6

Results of the correlation between mean forecast error and forecast revision: per horizon and pooled

\begin{tabular}{|c|c|c|c|c|c|c|}
\hline horizon & Inflation & RGDP & $\mathrm{CC} / \mathrm{GDP}$ & Inflation & RGDP & CC/GDP \\
\hline & & 2001-2006 & & & $2001-2010$ & \\
\hline $\mathrm{h}=1$ & $\begin{array}{l}-0.131 \\
(0.445) \\
\end{array}$ & $\begin{array}{l}-0.306^{*} \\
(0.069) \\
\end{array}$ & $\begin{array}{l}-0.051 \\
(0.765) \\
\end{array}$ & $\begin{array}{l}0.075 \\
(0.955)\end{array}$ & $\begin{array}{l}-0.222 * \\
(0.088)\end{array}$ & $\begin{array}{l}-0.287 * * \\
(0.026)\end{array}$ \\
\hline$h=2$ & $\begin{array}{l}-0.041 \\
(0.828)\end{array}$ & $\begin{array}{l}0.210 \\
(0.265)\end{array}$ & $\begin{array}{l}-0.238 \\
(0.204)\end{array}$ & $\begin{array}{l}0.700 * * * \\
(0.000)\end{array}$ & $\begin{array}{l}0.179 \\
(0.195)\end{array}$ & $\begin{array}{l}-0.213 \\
(0.121)\end{array}$ \\
\hline$h=3$ & $\begin{array}{l}-0.138 \\
(0.467)\end{array}$ & $\begin{array}{l}-0.027 \\
(0.885)\end{array}$ & $\begin{array}{l}0.016 \\
(0.931) \\
\end{array}$ & $\begin{array}{l}0.185 \\
(0.181)\end{array}$ & $\begin{array}{l}-0.224 * \\
(0.102)\end{array}$ & $\begin{array}{l}-0.344 * * * \\
(0.01)\end{array}$ \\
\hline$h=4$ & $\begin{array}{l}-0.295 \\
(0.113)\end{array}$ & $\begin{array}{l}-0.319 * \\
(0.085)\end{array}$ & $\begin{array}{l}-0.106 \\
(0.578)\end{array}$ & $\begin{array}{l}-0.077 \\
(0.577)\end{array}$ & $\begin{array}{l}-0.316^{* * *} \\
(0.02)\end{array}$ & $\begin{array}{l}0.049 \\
(0.725)\end{array}$ \\
\hline$h=5$ & $\begin{array}{l}0.021 \\
(0.910) \\
\end{array}$ & $\begin{array}{l}0.215 \\
(0.254)\end{array}$ & $\begin{array}{l}0.363 * * \\
(0.049)\end{array}$ & $\begin{array}{l}0.753 * * * \\
(0.000)\end{array}$ & $\begin{array}{l}0.109 \\
(0.433)\end{array}$ & $\begin{array}{l}0.265^{*} \\
(0.052) \\
\end{array}$ \\
\hline$h=6$ & $\begin{array}{l}-0.137 \\
(0.469) \\
\end{array}$ & $\begin{array}{l}0.175 \\
(0.355) \\
\end{array}$ & $\begin{array}{l}-0.073 \\
(0.701) \\
\end{array}$ & $\begin{array}{l}-0.067 \\
(0.631) \\
\end{array}$ & $\begin{array}{l}-0.180 \\
(0.192) \\
\end{array}$ & $\begin{array}{l}-0.078 \\
(0.573) \\
\end{array}$ \\
\hline$h=7$ & $\begin{array}{l}-0.143 \\
(0.449) \\
\end{array}$ & $\begin{array}{l}0.199 \\
(0.291) \\
\end{array}$ & $\begin{array}{l}0.176 \\
(0.353) \\
\end{array}$ & $\begin{array}{l}-0.217 \\
(0.115) \\
\end{array}$ & $\begin{array}{l}-0.174 \\
(0.208) \\
\end{array}$ & $\begin{array}{l}-0.046 \\
(0.738) \\
\end{array}$ \\
\hline$h=8$ & $\begin{array}{l}-0.371 * * \\
(0.043)\end{array}$ & $\begin{array}{l}0.301 \\
(0.106) \\
\end{array}$ & $\begin{array}{l}-0.108 \\
(0.568) \\
\end{array}$ & $\begin{array}{l}-0.005 \\
(0.972) \\
\end{array}$ & $\begin{array}{l}0.133 \\
(0.414) \\
\end{array}$ & $\begin{array}{l}0.062 \\
(0.653) \\
\end{array}$ \\
\hline $\mathrm{h}=9$ & $\begin{array}{l}-0.165 \\
(0.383) \\
\end{array}$ & $\begin{array}{l}0.189 \\
(0.316) \\
\end{array}$ & $\begin{array}{l}-0.198 \\
(0.294) \\
\end{array}$ & $\begin{array}{l}-0.158 \\
(0.253) \\
\end{array}$ & $\begin{array}{l}0.021 \\
(0.882) \\
\end{array}$ & $\begin{array}{l}0.145 \\
(0.295) \\
\end{array}$ \\
\hline $\mathrm{h}=10$ & $\begin{array}{l}-0.297 \\
(0.110) \\
\end{array}$ & $\begin{array}{l}0.028 \\
(0.883) \\
\end{array}$ & $\begin{array}{l}0.173 \\
(0.359) \\
\end{array}$ & $\begin{array}{l}0.420 * * * \\
(0.001)\end{array}$ & $\begin{array}{l}-0.299 * * \\
(0.028) \\
\end{array}$ & $\begin{array}{l}0.248^{*} \\
(0.07) \\
\end{array}$ \\
\hline$h=11$ & $\begin{array}{l}0.151 \\
(4.23) \\
\end{array}$ & $\begin{array}{l}0.043 \\
(0.822) \\
\end{array}$ & $\begin{array}{l}-0.363 * * \\
(0.049) \\
\end{array}$ & $\begin{array}{l}-0.173 \\
(0.211) \\
\end{array}$ & $\begin{array}{l}-0.308 * * \\
(0.023) \\
\end{array}$ & $\begin{array}{l}0.068 \\
(0.621) \\
\end{array}$ \\
\hline $\mathrm{h}=12$ & $\begin{array}{l}0.297 \\
(0.111) \\
\end{array}$ & $\begin{array}{l}-0.186 \\
(0.324) \\
\end{array}$ & $\begin{array}{l}0.064 \\
(0.738) \\
\end{array}$ & $\begin{array}{l}-0.260 * \\
(0.057) \\
\end{array}$ & $\begin{array}{l}-0.506^{* * * *} \\
(0.000) \\
\end{array}$ & $\begin{array}{l}-0.160 \\
(0.247) \\
\end{array}$ \\
\hline $\begin{array}{l}\text { Current year } \\
\text { (pooled) }\end{array}$ & $\begin{array}{l}0.067 \\
(0.198) \\
\end{array}$ & $\begin{array}{l}-0.018 \\
(0.731) \\
\end{array}$ & $\begin{array}{l}-0.012 \\
(0.816) \\
\end{array}$ & $\begin{array}{l}-0.060 \\
(0.124) \\
\end{array}$ & $\begin{array}{l}-0.205 * * * \\
(0.000) \\
\end{array}$ & $\begin{array}{l}0.018 \\
(0.633) \\
\end{array}$ \\
\hline $\mathrm{h}=13$ & $\begin{array}{l}-0.085 \\
(0.628) \\
\end{array}$ & $\begin{array}{l}0.078 \\
(0.651)\end{array}$ & $\begin{array}{l}-0.289 * \\
(0.087)\end{array}$ & $\begin{array}{l}-0.260 * * \\
(0.046)\end{array}$ & $\begin{array}{l}-0.415 * * * \\
(0.001)\end{array}$ & $\begin{array}{l}-0.162 \\
(0.216) \\
\end{array}$ \\
\hline $\mathrm{h}=14$ & $\begin{array}{l}0.099 \\
(0.600)\end{array}$ & $\begin{array}{l}-0.432 * * \\
(0.017)\end{array}$ & $\begin{array}{l}-0.009 \\
(0.960)\end{array}$ & $\begin{array}{l}-0.229 * \\
(0.096)\end{array}$ & $\begin{array}{l}-0.328 * * \\
(0.015)\end{array}$ & $\begin{array}{l}-0.043 \\
(0.757)\end{array}$ \\
\hline$h=15$ & $\begin{array}{l}0.062 \\
(0.742)\end{array}$ & $\begin{array}{l}-0.501 * * * \\
(0.004)\end{array}$ & $\begin{array}{l}-0.047 \\
(0.803) \\
\end{array}$ & $\begin{array}{l}0.080 \\
(0.566) \\
\end{array}$ & $\begin{array}{l}-0.679 * * * \\
(0.000)\end{array}$ & $\begin{array}{l}0.062 \\
(0.656) \\
\end{array}$ \\
\hline$h=16$ & $\begin{array}{l}-0.195 \\
(0.301) \\
\end{array}$ & $\begin{array}{l}-0.111 \\
(0.558)\end{array}$ & $\begin{array}{l}-0.245 \\
(0.191) \\
\end{array}$ & $\begin{array}{l}-0.311 * \\
(0.022)\end{array}$ & $\begin{array}{l}-0.415 * * * \\
(0.002)\end{array}$ & $\begin{array}{l}0.054 \\
(0.699) \\
\end{array}$ \\
\hline$h=17$ & $\begin{array}{l}0.105 \\
(0.580)\end{array}$ & $\begin{array}{l}-0.024 \\
(0.898) \\
\end{array}$ & $\begin{array}{l}0.324 * \\
(0.080)\end{array}$ & $\begin{array}{l}0.547 * * * \\
(0.000)\end{array}$ & $\begin{array}{l}-0.103 \\
(0.460)\end{array}$ & $\begin{array}{l}0.401 * * * \\
(0.002)\end{array}$ \\
\hline $\mathrm{h}=18$ & $\begin{array}{l}-0.154 \\
(0.414) \\
\end{array}$ & $\begin{array}{l}0.298 \\
(0.110) \\
\end{array}$ & $\begin{array}{l}-0.207 \\
(0.271) \\
\end{array}$ & $\begin{array}{l}0.133 \\
(0.337)\end{array}$ & $\begin{array}{l}-0.167 \\
(0.226) \\
\end{array}$ & $\begin{array}{l}-0.046 \\
(0.738)\end{array}$ \\
\hline $\mathrm{h}=19$ & $\begin{array}{l}-0.165 \\
(0.381) \\
\end{array}$ & $\begin{array}{l}-0.006 \\
(0.973) \\
\end{array}$ & $\begin{array}{l}0.066 \\
(0.730) \\
\end{array}$ & $\begin{array}{l}0.188 \\
(0.172) \\
\end{array}$ & $\begin{array}{l}0.005 \\
(0.972) \\
\end{array}$ & $\begin{array}{l}0.062 \\
(0.653) \\
\end{array}$ \\
\hline $\mathrm{h}=20$ & $\begin{array}{l}-0.173 \\
(0.360) \\
\end{array}$ & $\begin{array}{l}0.261 \\
(0.163) \\
\end{array}$ & $\begin{array}{l}0.004 \\
(0.983) \\
\end{array}$ & $\begin{array}{l}0.226^{*} \\
(0.100) \\
\end{array}$ & $\begin{array}{l}-0.302 * * \\
(0.026) \\
\end{array}$ & $\begin{array}{l}0.191 \\
(0.166) \\
\end{array}$ \\
\hline $\mathrm{h}=21$ & $\begin{array}{l}-0.300 * \\
(0.107)\end{array}$ & $\begin{array}{l}0.192 \\
(0.308)\end{array}$ & $\begin{array}{l}-0.114 \\
(0.547)\end{array}$ & $\begin{array}{l}0.118 \\
(0.395)\end{array}$ & $\begin{array}{l}-0.025 \\
(0.857)\end{array}$ & $\begin{array}{l}0.166 \\
(0.228)\end{array}$ \\
\hline $\begin{array}{l}\text { Next year } \\
\text { (pooled) }\end{array}$ & $\begin{array}{l}-0.048 \\
(0.426) \\
\end{array}$ & $\begin{array}{l}0.0185 \\
(0.758) \\
\end{array}$ & $\begin{array}{l}-0.037 \\
(0.540) \\
\end{array}$ & $\begin{array}{l}0.048 \\
(0.281) \\
\end{array}$ & $\begin{array}{l}-0.210 * * * \\
(0.000)\end{array}$ & $\begin{array}{l}0.124 * * * \\
(0.006)\end{array}$ \\
\hline
\end{tabular}

Note: p-value between ().*,**,*** imply statistical significance at 10,5 and $1 \%$, respectively. The forecasts are for annual economic growth over the current and next calendar year: the forecast horizon (dated to the end of the forecast year) therefore varies from 1 to 24 months. 


\section{References}

Ager, P., M. Kappler and S. Osterloh (2009), "The accuracy and efficiency of the Consensus Forecasts: A further application and extension of the pooled approach" International Journal of Forecasting 25(1), 167-181.

Bauer, A., R. Eisenbeis, D. Waggoner and T. Zha (2006), "Transparency, expectations and forecasts" Economic Review 91(1).

Capistran, C. and M. Ramos-Francia (2010), "Does Inflation Targeting Affect the Dispersion of Inflation Expectations?", Journal of Money, Credit and Banking 42(1), 113-134.

Cechetti, S.G. and Craig S. Hakkio (2010), "Inflation targeting and private sector forecasts." Research Working Paper RWP 10-01. Federal Reserve Bank of Kansas City.

Chen, Q, M. Costantini and B. Deschamps (2016), "How accurate are the professional forecasts in Asia? Evidence from ten countries", International Journal of Forecasting 32(1), 154-167.

Crowe, C. and Ellen E. Meade (2008), "Central Bank Independence and Transparency: Evolution and effectiveness." European Journal of Political Economy 24(4), 763-777.

Crowe, C. (2010a), "Testing the Transparency Benefits of Inflation Targeting: Evidence from Private Sector Forecasts.” Journal of Monetary Economics 57(2), 226-232.

Crowe, C. (2010b), "Consensus forecasts and inefficient information aggregation." Research paper. IMF Working Paper 10/178 (Washington: International Monetary Fund).

Davies, A. and Lahiri, K., (1995), "A new framework for analyzing survey forecasts using three-dimensional panel data," Journal of Econometrics 68(1), 205-227.

Dincer, N. and B. Eichengreen (2010), "Central Bank Transparency: Causes, Consequences and Updates." Theoretical Inquiries in Law: 11(1). Article 5. http://www.bepress.com/til/default/vol11/iss1/art5

Dincer, N. and B. Eichengreen (2014), "Central Bank transparency and independence: Updates and new measures." International Journal of Central Banking 10(1), 189-253.

Dovern, J., U. Fritsche and J. Slacalek (2012), "Disagreement Among Forecasters in G7 Countries." Review of Economics and Statistics 94(4), 1081-1096.

Dovern J., U. Fritsche, P. Loungani and N. Tamirisa (2015),"Information rigidities: Comparing average and individual forecasts for a large international panel." International Journal of Forecasting 31(1), 144-154.

Ehrmann, M., S. Eijffinger and M. Fratzscher (2012), "The Role of Central Bank Transparency for guiding private sector forecasts." Scandinavian Journal of Economics 114(3), 1018-1052. Geraats, P. M. (2002), "Central bank transparency" The Economic Journal 112(483), 532-565. Gürkaynak, R., A. Levin and E. Swanson (2010), "Does Inflation Targeting Anchor Long-Run Inflation Expectations? Evidence from the U.S., U.K., and Sweden', Journal of the European Economic Association 8, 1208-1242.

Hubert, P (2013), "The influence and policy signaling role of FOMC forecasts," Documents de Travail de l'OFCE 2013-03, Observatoire Francais des Conjonctures Economiques (OFCE).

Hubert, P (2014), "Disentangling qualitative and quantitative central bank influence." Sciences Po publications 23.

Isiklar, G., K. Lahiri, and P. Loungani (2006), "How quickly do forecasters incorporate news? Evidence from cross-country surveys. " Journal of Applied Econometrics 21, 703-725

Johnson, D. (2002), "The effect of inflation targeting on the behavior of expected inflation." Journal of Monetary Economics 49, 1521-1538.

Kim, Oliver, Steve C. Lim and Kenneth W. Shaw (2001), "The Inefficiency of the Mean Analyst Forecast as a Summary Forecast of Earnings." Journal of Accounting Research 39, 329-336.

Lahiri, K. and Sheng, X. (2008), "Evolution of forecast disagreement in a Bayesian learning model." Journal of Econometrics 144, 325-340. 
Loungani, P. (2001), "How accurate are private sector forecasts? Cross-country evidence from consensus forecasts of output growth." International Journal of Forecasting, 17, 419-432.

Loungani, P., H. Steckler and N. Tamirisa (2013), "Information rigidity in growth forecasts: Some cross-country evidence". International Journal of Forecasting 29, 605-621.

Mankiw, N., Gregory R. Reis, and J. Wolfers (2003), "Disagreement About Inflation Expectations." NBER Macroeconomics Annual 2003. Cambridge. MIT Press. 18, 209-248.

Middeldorp, M. (2011), "Central bank transparency, the Accuracy of professional forecasts, and interest rate volatility." Staff Reports 496. Federal Reserve Bank of New York.

Minegishi, M. and B. Cournède (2009), "The Role of Transparency in the Conduct of Monetary Policy," OECD Economics Department Working Papers 724, OECD Publishing.

Mioh, F., M. Saifur Rahman, and K. Albinali (2016), "Rationality of based inflation expectations: A study of 18 emerging economies' inflation forecasts", Research in International Business and Finance 36, 158-166.

Morris, S. and H. S. Shin (2002), "The Social Value of Public Information." American Economic Review 92, 1521-1534.

Morris, S. and H. S. Shin (2008), "Coordinating expectations in monetary policy", in: Central Banks as Economic Institutions, chapter 5 Edward Elgar.

Pétursson, Thorarinn G. (2004), "Formulation of inflation targeting around the World." Monetary Bulletin, 57-84.

Sellon, Gordon H. Jr. (2008), "Monetary policy transparency and private sector forecasts: Evidence from survey data", Federal Reserve Bank of Kansas Economic Review 93(3), 7-34.

Siklos, Pierre L. (2003), "Assessing the Impact of Changes in Transparency and Accountability at the Bank of Canada" Canadian Public Policy - Analyses de Politiques 29(3), 279-299.

Siklos, Pierre L. (2010), "Sources of disagreement in inflation forecasts: A cross-country empirical investigation", IMES Discussion Paper Series 10-E-26 Institute for Monetary and Economic Studies, Bank of Japan

Van der Cruijsen, Carin A.B., Sylvester C.W. Eijffinger, and Lex H Hoogduin (2010), “Optimal Central Bank Transparency”. Journal of International Money and Finance 29(8), 1482-1507. 